\title{
Cottonballs, a unique subaqeous moonmilk, and abundant subaerial moonmilk in Cataract Cave, Tongass National Forest, Alaska
}

\author{
Megan D. Curry ${ }^{1,2}$, Penelope J. Boston ${ }^{1,2}$, Mike N. Spilde ${ }^{3}$, James F. Baichtal ${ }^{4}$,
}

Andrew R. Campbell ${ }^{1}$

\begin{abstract}
:
Curry M.D., Boston P.J., Spilde M.N., Baichtal J.F., Campbell A.R. 2009. Cottonballs, a unique subaqeous moonmilk and abundant subaerial moonmilk in Cataract Cave, Tongass National Forest, Alaska. International Journal of Speleology, 38(2), 111-128. Bologna (Italy). ISSN 0392-6672.

The Tongass National Forest is known for its world-class karst features and contains the largest concentration of dissolutional caves in Alaska. Within these karst systems exist unusual and possibly unique formations exhibiting possible biological origin or influence. Cataract Cave is an example of such a system. This cave hosts a unique depositional setting in which so-called "cottonballs" line two permanent pools. The cottonballs are a calcitic deposit heavily entwined within a mass of microbial filaments. They are juxtaposed with extensive subaerial calcitic moonmilk wall deposit of a more conventional nature but of an extraordinary thickness and abundance.

Both the cottonballs and moonmilk are composed of microcrystalline aggregates $(0.20 \mathrm{wt} . \%)$ compared to the cottonballs $(0.12 \mathrm{wt} . \%)$. However, the cottonballs are dominated by monocrystalline needles, whereas the moonmilk is mainly composed of polycrystalline needles. The microbial environments of both displayed similar total microbial cell counts; however, culturable microbial counts varied between the deposits and among the various media. For both, in situ cultures and isolates inoculated in a calcium salt medium produced calcium carbonate mineralization within biofilms. Geochemical variations existed between the deposits. Moonmilk displayed a slightly higher abundance of organic carbon $(0.20 \mathrm{wt} \%)$ compared to the cottonballs $(0.12 \mathrm{wt} \%)$. Stable isotopic analysis revealed that the moonmilk $(\delta 13 \mathrm{C}=-1.6 \%)$ was isotopically heavier compared to the cottonballs $(\delta 13 \mathrm{C}=-8.1 \%)$ but both are lighter than the host rock $(\delta 13 \mathrm{C}=+1.1 \%)$. However, the organic carbon $\delta 13 \mathrm{C}$ values of both deposits were similar $(\delta 13 \mathrm{C}=-27.4$ and $-26.7 \%)$ and isotopically lighter compared to other overlying surface organic carbon sources.

Due to the similarities between the deposits, we infer that both the cottonballs and moonmilk are subject to a set of related processes that could collectively be accommodated by the term "moonmilk". Thus, the cottonball pool formation can be characterized as a type of subaqueous moonmilk. The differences observed between the moonmilk and cottonballs may be largely attributable to the changes in the depositional environment, namely in air or water.
\end{abstract}

Keywords: cottonballs; moonmilk; USA, Alaska, Tongass National Forest; subaqueous

Received 22 January 2009; Revised 3 March 2009; Accepted 5 May 2009

\section{INTRODUCTION}

Cataract Cave in the Tongass National Forest contains a white unconsolidated wall deposit of a speleothem known as "moonmilk". This deposit is juxtaposed with a potentially unique pool deposit composed of white, puffy structures lying on the pool bottom and dubbed "cottonballs" (Figure 1). Moonmilk

1. Department of Earth \& Environmental Sciences, New Mexico Institute of Mining and Technology, Socorro, NM 87801

2. National Institute of Cave and Karst Research, Carlsbad, New Mexico

3. Institute of Meteoritics, University of New Mexico, MSC03-

2050, 1 Univ. of New Mexico, Albuquerque, NM 87131

4. Tongass National Forest, Thorne Bay Ranger District, P.O.

Box 19001, Thorne Bay, Alaska 99919 is a well known speleothem while the cottonballs have been reported from Cataract Cave but not previously characterized (Allred, 1992; Hill \& Forti, 1997).

Moonmilk is currently defined as a microcrystalline aggregate cave deposit with variable mineralogy, a high water content, a high porosity, and distinguishable macro- and micro-texture (Hill \& Forti, 1997). Various compositions have been reported including common cave minerals such as calcite, aragonite and hydromagnesite and other non-carbonate minerals such as silicates, phosphates, and sulfates (Onac \& Ghergari, 1993; Hill \& Forti, 1997; Moore \& Sullivan, 1997; Borsato et al., 2000; Lacelle et al., 2004; B. Rogers, pers. comm.). This array of minerals is attributable to various host lithologies (Gradziñski et al., 1997) and water chemistry associated with each cave. Therefore, the term moonmilk is useful as a 

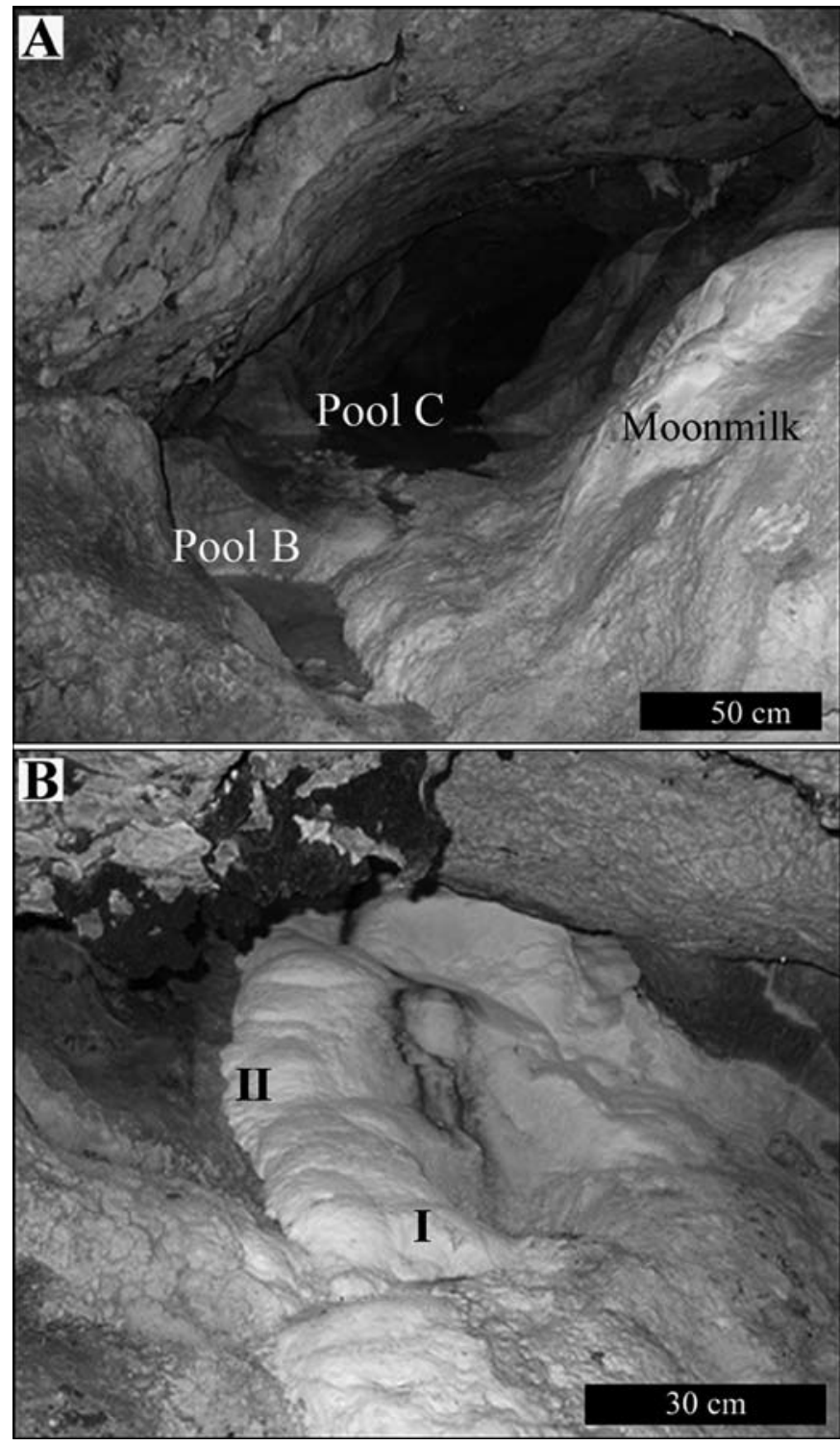

Fig. 1. (A) Overview of the upper section side passage showing the spatial relationship of the permanent pools and moonmilk. (B) Closer view of the white and yellow moonmilk deposit forming on the sidewall of the passage. I and II indicate the sampling sites. (Photos taken by A. Martin Perez and J. Baichtal)

textural, but not a mineralogical, definition.

Hydrated moonmilk has a soft, pasty and plastic texture with water content varying from 40-80\% (Hill \& Forti, 1997; Perrone, 2005). Lacelle et al. (2004) report water content of 40-70\%, and Gèze (1976) reported water content as high as $96 \%$. In contrast, other deposits are powdery and dry due to a low water content (12-40\%). Diagenetic alteration has been suggested for such variations within deposits, in which dry and, thus, presumably inactive deposits have been subjected to early non-burial vadose diagenesis (Gradziñski et al., 1997).

The morphology of moonmilk is as varied as its composition. Some types have a cauliflower-like appearance with a greasy, lard-like texture, whereas other types are knobby, rounded or simply pastelike. Microscopically, the most diagnostic calcitic moonmilk feature is its needle-shaped, or fibrous crystal morphology, which appears as unstructured aggregates of micrometer to nanometer-sized crystals with no apparent preferred orientation (e.g., Onac, 1995; Gradziñski et al., 1997; Hill \& Forti, 1997; Borsato et al., 2000; Cañaveras et al., 2006). Secondarily, moonmilk that is considered to be biologically active also contains a significant biological presence including cells, filaments, and apparent biofilm (Gradziñski et al., 1997; Boston et al., 2001). Highly filamentous calcitic moonmilk has been found in La Cueva de Las Barrancas and Spider Cave, New Mexico, and a hydromagnesite version in La Tetera Cave near Tucson, Arizona (P.J. Boston, unpublished observations). It is probably relatively widely distributed but less commonly reported since the filamentous nature is only apparent when specimens are examined with electron microscopy rather than at the hand lens scale.

To date, moonmilk has been reported worldwide in a variety of different countries and climates from alpine to tropical (Hill \& Forti, 1997; Ford \& Williams, 2007; B. Rogers, unpublished database). Examples of this global distribution include the U.S.A. (e.g. New Mexico, Colorado, Alaska), México (P.J. Boston, unpublished observations), Venezuela (Hill \& Forti, 1997), Norway (Høeg, 1946; Onac, 1995), Poland (Gradziñski et al., 1997), Spain (Cañaveras et al., 2006; Martìn-Pèrez, 2006; Martinez-Arkarazo et al., 2007), Italy (Borsato et al., 2000; Blyth \& Frisia, 2008), Slovenia (Mulec et al., 2002), Switzerland (Fischer, 1988; Bernasconi, 1976), Romania (Onac \& Ghergari, 1993; Chirienco, 2002), Germany (Richter et al., 2008), Ukraine (Klimchouk \& Gudzenko, 1996), and Australia (van de Kamp, 2004).

Cottonballs are peculiar moonmilk-like subaqueous deposits according to Hill \& Forti (1997). They were reported briefly in Allred (1992) and Hill \& Forti (1997), but have not been the subject of prior study. They are uncompacted apparently authigenic calcite deposits that appear as puffy, white aggregates lining the bottom of several permanent cave pools. There are similar reports of subaqueous moonmilk for Blue Pool in Groaning Cave, Colorado (D. Davis, personal communication in Hill \& Forti, 1997), Faustlöch Cave in Switzerland (U. Widmir, personal communication in Hill \& Forti, 1997) and Caverna Santana in Brazil (Barbieri, 1983).

Questions that can be asked about moonmilk include: what is the role of water availability in moonmilk formation, what is the depositional setting (subaerial or subaqueous or both), are microorganisms essential to moonmilk formation, and critically what is the role of organic carbon and other nutrients from the aboveground environment in moonmilk production?

\section{MATERIAL AND METHODS}

\section{Field Study Approach}

Because this was a preliminary reconnaissance study, we have chosen to take a very broad approach and have gathered a number of different types of data to enable us to build a comprehensive picture of the speleothems in context rather than focus heavily on any individual analysis. We have utilized in situ sampling of mineral 
and biological materials, aqueous measurements (such as $\mathrm{pH}$, temperature, and electric conductivity), scanning electron microscopy (SEM), and limited enrichment culture techniques. Field information gathered included: geological and biological observations and descriptions, and measurements for deposits and pools. Samples were collected from two sample sites for the moonmilk (Figure 1) and three sample sites for the cottonball deposits (Figure 4). Pool water temperature, $\mathrm{pH}$, electric conductivity, and salinity were measured using a hand-held field HANNA Combo Meter and Horiba compact $\mathrm{pH}$ meter (accuracy, \pm $0.5^{\circ} \mathrm{C}$ temp, $\mathrm{pH} \pm 0.05, \pm 2 \%$ f.s.E.C.).

\section{Site Description}

Cataract Cave is located within a coastal temperate rainforest in the Tongass National Forest, Prince of Wales Island (POWI), in southeastern Alaska (Figure 2). Mature, well-developed western hemlock-Sitka spruce forests characterize the valley floors and low-gradient slopes (Baichtal \& Swanston, 1996). Average annual precipitation for POWI's karst terrain varies from 1.5 meters to more than 6.4 meters per year (Baichtal \& Swanston, 1996) compared to 2.5 meters for the whole island (Allred, 2004). Average annual air temperature for the whole island is $7.2^{\circ} \mathrm{C}$ (Allred, 2004). The majority of karst terrain (including Cataract Cave) is found within the Silurian Heceta Limestone, characterized as a fine-grained, massive limestone, which is commonly fractured and fossiliferous. The main factor contributing to limestone dissolution in this region is the overlying organic rich soils and peatlands creating acidic groundwater (Baichtal \& Swanston, 1996).

Cataract is a limestone dissolutional cave with canyon-like passages implying vadose development. This cave is composed of a lower part and an upper segment (Figure 3), with a perennial resurgent stream that flows through the lower part at $\sim 40$ liters per second at $8.5^{\circ} \mathrm{C}$ (Allred, 1992; Allred, 2004). Closely spaced scallops in the lower passage indicate high velocity paleo-flows (Allred, 1992).

A parallel side passage in the lower segment contains no streams, but permanent pools are present. When ascending to the upper area, one encounters a plunge pool at the top of an inactive waterfall. This section of the passage is $\sim 1.5$ meters in width and 4.6 meters in height. The air temperature of the passage was $7.8^{\circ} \mathrm{C}$ (June). Pool A is 8 to $40 \mathrm{~cm}$ deep and contains no calcite or other mineral deposits.

In a smaller side passage $(0.6$ to 3.0 meters in height and 0.76 to 1.5 meters wide), two small permanent pools (Pool B and Pool C, Figure 4) are present. The pools are both less than a square meter each and shallow, 7 and $13 \mathrm{~cm}$ in depth, respectively. Both pools are lined with the calcite cottonball deposits. The cottonballs occur in spatially compact regions and consist of white, bulbous microcrystalline calcitic "aggregates" of varying diameter and height that line the bottom of the pool. They resemble a dense field of submerged cauliflower heads with the texture of cottonballs (Figure 4). The cottonballs in Pool $\mathrm{C}$ are larger in diameter $(5-15 \mathrm{~cm})$ and $1-5 \mathrm{~cm}$ in height. Figure 5 displays photo documentation showing

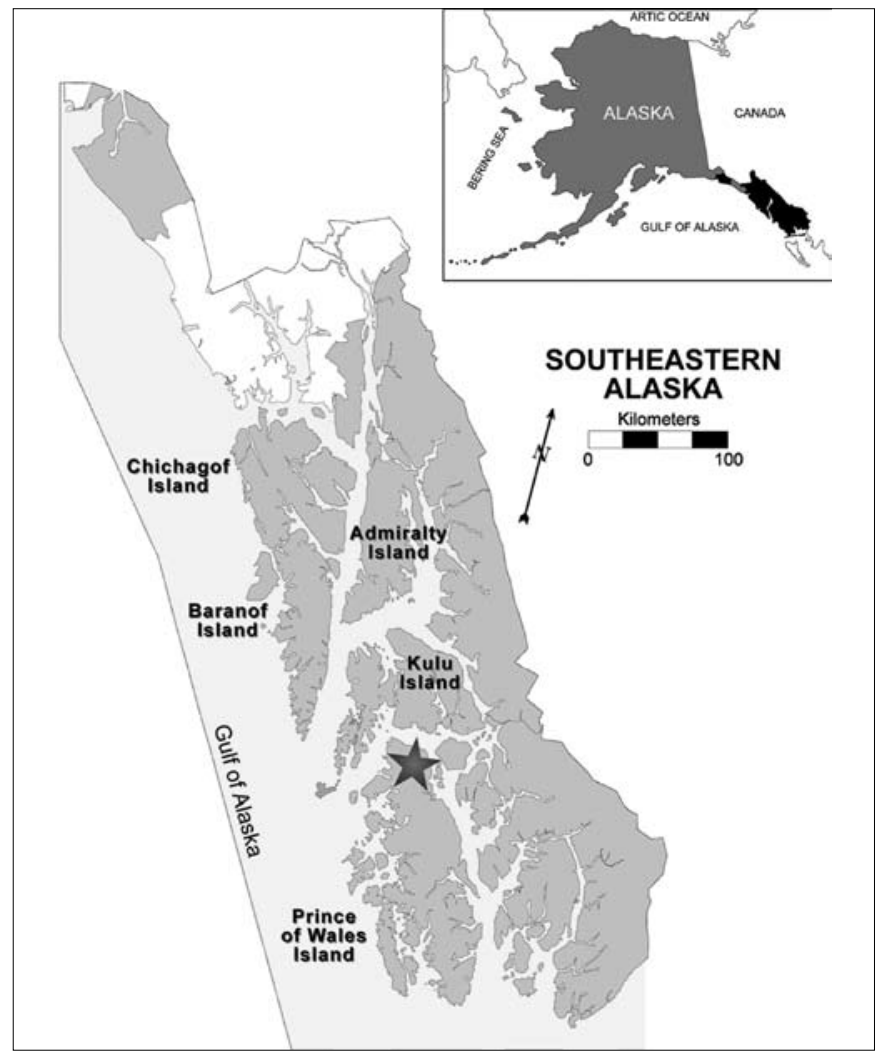

Fig. 2. Geographical location of the study site, Prince of Wales Island, Tongass National Forest (shaded black in upper corner inset), southeastern Alaska. Modified from the United States Forest map from Baichtal \& Swanston, 1996.

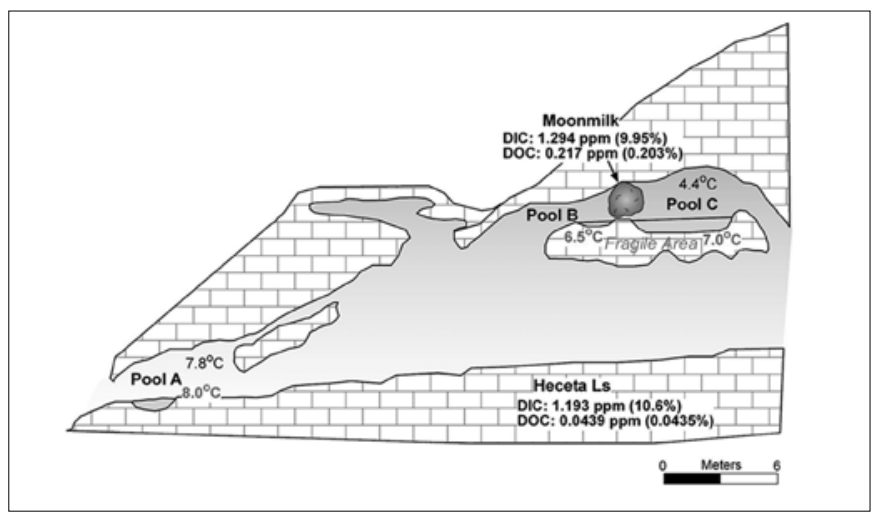

Fig. 3. Cross sectional view showing the spatial relationships among the passages, pools, and deposits located within Cataract Cave (Modified from Allred, 1992).

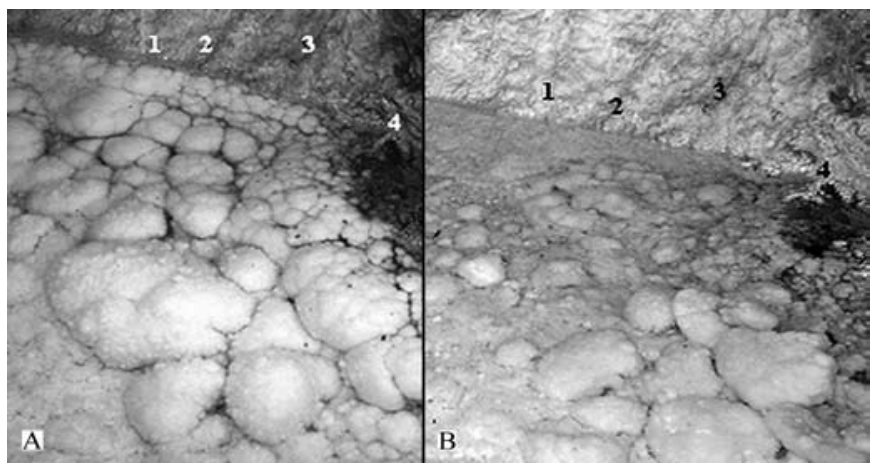

Fig. 5. Photo documentation showing significant variation of pool $C$ cottonball deposits in (A) June 1991 and (B) June 2007. Numbers represent reference points to compare and contrast any changes that may have occurred such as water level or depositional growth (Photos taken by A. Martin Perez and J. Baichtal). 


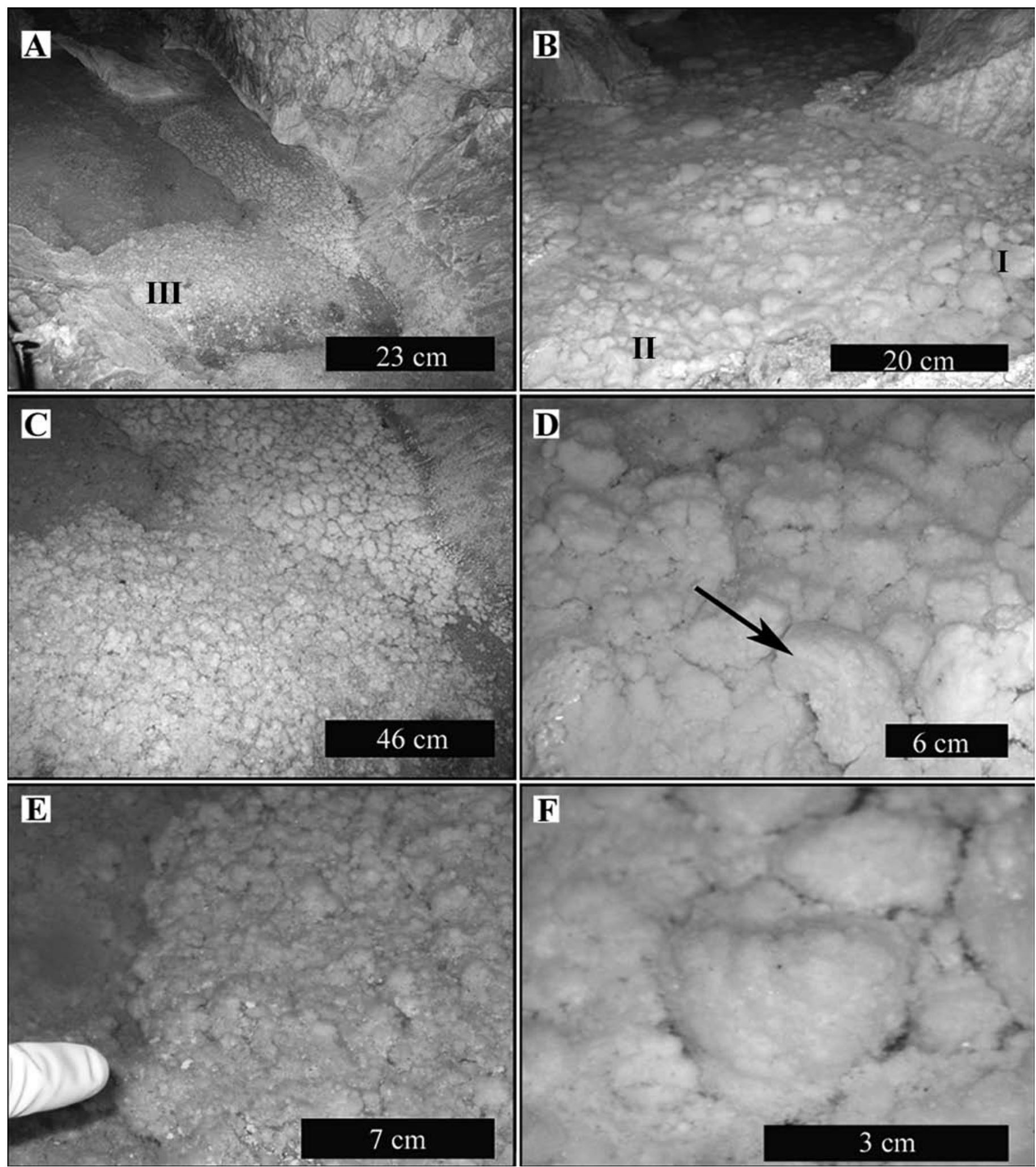

Fig. 4. Sequence of photos from an overview of pool deposit to closer views of the mineral deposits lining the bottom of the pools. (A, C, E) Pool B and (B, D, F) Pool C. The roman numerals I, II, and III indicate the various sampling sites for the cottonballs. Arrow in (D) points toward the faint banding present associated with some of the cottonballs (Photos taken by A. Martin Perez and J. Baichtal).

great variation of the Pool C cottonball deposition between 1991 and sixteen years later in 2007. After over a decade and a half, the cottonballs appear less numerous and fluffy. Further observation of the deposits and environmental monitoring (e.g., surface and cave) are needed in order to better understand the possible causes of this variation including hydrological influences, episodic subaerial exposure, mechanical disturbances, changes in pool chemistry, local climatic changes, seasonal changes, or aging of the deposit.

The cottonballs in pool $\mathrm{B}$ are smaller $(1-3.5 \mathrm{~cm}$ in diameter and 0.5-1.5 cm in height) and display a slight difference in surface morphology compared to pool C. These deposits have a knobbier surface appearance (similar to miniature anemones), are tan in color, and are underlain by an apparently continuous calcite layer (Figure 4). Table 1 compares the field measurements 
of the three pools. Figure 4 illustrates the textural and size variations of the cottonballs between the pools.

A small intermittent channel $(60 \mathrm{~cm}$ in length) connects the two pools with Pool C slightly elevated above Pool B. Adjacent to the pools is a white and pale yellow, felted moonmilk deposit that coats a sidewall (Figure 1). This close proximity of the different subaqueous and subaerial deposits raises the question whether the deposits could be related or different from one another. Another interesting question is why deposition occurs at the subaqueous rock-water interface and not the air-water interface as is typically seen with speleothems like calcite rafts.

\section{Geomicrobial Methods}

Cultivation

We elected to conduct a mineral crystallization potential screening for microorganisms in the moonmilk and cottonballs. We sought to grow strains or assemblages capable of nucleating or otherwise facilitating calcite precipitation. This was not intended to be an identification of the biodiversity in the cave, but a biomineralization plausibility study. In situ cultivation consisted of an array of various selective, complex, and defined media from previous studies (Danielli \& Edington, 1983; Boston et al., 2001, Perrone, 2004, van de Kamp, 2004), along with other experimental media. In total, twenty media were employed (Table 2). The various media were used to test for an array of different metabolic types of potential relevance to candidate moonmilk formation processes. Media were aseptically inoculated in situ for each deposit. After inoculation, cultures were refrigerated during transport. In the lab, the cultures were then incubated in the dark at $6^{\circ} \mathrm{C}$. Samples were later analyzed for mineralization, bacterial, and fungal growth. Other media slants were transported to the cave, not inoculated and then transported back to the lab as negative controls.

In situ cultures with positive crystallization results were evaluated and streaked for isolation. Colonies associated with crystallization were isolated and incubated at $25^{\circ} \mathrm{C}$. Three transfer generations were used with duplicates and appropriate controls. Crystal morphology and composition of any minerals present in the cultures were evaluated using SEM coupled with energy dispersive X-ray spectrometry (EDS).

Table 1. Field measurements among the three pools. Pool (A) is a permanent pool in the lower level that contains no calcite deposition, while pools $(B)$ and $(C)$ are the permanent pools in the upper passage that contain the cottonball deposits juxtaposed on the moonmilk deposit. The surface temperature was $13^{\circ} \mathrm{C}$ (August).

\begin{tabular}{|c|c|c|c|}
\hline & Pool A & Pool B & Pool C \\
\hline $\mathrm{H}_{2} \mathrm{O}$ Temperature $\left({ }^{\circ} \mathrm{C}\right)$ & 8.0 (June) 8.3 (Aug.) & 6.5 (June) 8.9 (Aug.) & 7.0 \\
\hline Air Temperature $\left({ }^{\circ} \mathrm{C}\right)$ & 7.8 (June) 8.4 (Aug.) & 4.4 (June) 9.0 (Aug.) & 4.4 \\
\hline $\mathrm{pH}$ & 8.4 (Field) 8.1 (Lab) & 8.5 (Field) 8.2 (Lab) & 7.7 \\
\hline Conductivity (mS/cm) & 0.19 & 0.19 & 0.20 \\
\hline Salinity (ppt) & 0.09 & 0.09 & 0.09 \\
\hline
\end{tabular}

Table 2. List of cultivation media, corresponding medium references, and present carbon sources within each medium that were utilized in this study. Positive (+) and negative (-) symbols indicate the same results were observed for both deposits. Micro-environmental measurements were taken on June 14, 2007. If cultivation results varied between the deposits, either (CB) for cottonballs or (MM) for moonmilk is listed. Plate count results for the associated media are provided in the last column in colony forming units per gram of deposit (CFU/g).

\begin{tabular}{|c|c|c|c|c|c|}
\hline Medium & Reference & Carbon Source & $+/-$ & +/- Crystallization & CFU/g \\
\hline Arginine-Vitamin Agar & van de Kamp, 2004 & L-arginine, Glucose, Glycerol & + & - & \\
\hline Minimal Acetate Medium & van de Kamp, 2004 & Acetate & + & - & \\
\hline Starch-Casein Agar & van de Kamp, 2004 & Soluble Starch, Casein & + & - & \\
\hline Tryptone Soy Agar (1/2 Strength) & TSA Fisher Scientific (S71627A) & $\begin{array}{c}\text { Pancreatic Digest of Casein, Papaic } \\
\text { Digest of Soybean Meal }\end{array}$ & + & - & \\
\hline Variant 2 & Danielli \& Edington, 1983 & Sodium Lactic Acid & + & $\mathrm{MM}, \mathrm{CB}$ & \\
\hline Variant 3 & Danielli \& Edington, 1983 & Calcium Succinate & + & CB only & $\begin{array}{l}\text { CB: } 3.20 \times 10^{4} \\
\text { MM: } 1.75 \times 10^{3}\end{array}$ \\
\hline Variant 4 & Danielli \& Edington, 1983 & Maltose & + & - & \\
\hline Variant 5 & Danielli \& Edington, 1983 & Calcium Succinate & $\mathrm{CB}$ only & - & \\
\hline Basal Salts (BS) & Perrone, 2005; Spilde et al., 2005 & None & + & - & \\
\hline$B S+R 2 A$ & Perrone, 2005 & $\begin{array}{l}\text { Yeast Extract, Proteose Peptone, } \\
\text { Casamino acids, Dextrose, Soluble }\end{array}$ & + & - & \\
\hline BS + Acetate & Perrone, 2005 & Acetate & + & - & \\
\hline Trace Metal Solution & Perrone, 2005 & None & - & - & \\
\hline $\begin{array}{l}\text { Reduced Arginine-Starch Salts w/ } \\
\text { Vitamins }\end{array}$ & Perrone, 2005 & Starch, Arginine & + & - & \\
\hline $1 / 2$ and $1 / 4$ Strength R2A & R2A (Difco) & $\begin{array}{l}\text { Yeast Extract, Proteose Peptone, } \\
\text { Casamino acids, Dextrose, Soluble }\end{array}$ & + & - & $\begin{array}{l}\text { CB: } 8.06 \times 10^{3} \\
\text { MM: } 1.04 \times 10^{5}\end{array}$ \\
\hline Actinomycete Isolation Agar & $\begin{array}{l}\text { Actionomycete Isolation Agar } \\
\text { (Difco) }\end{array}$ & Asparagine, Glycerol & + & - & \\
\hline Hyphomicrobium Medium & Atlas \& Parks, 1993 & Urea, methanol & + & + & $\begin{array}{l}\text { CB: } 6.20 \times 10^{4} \\
\text { MM: } 1.07 \times 10^{3}\end{array}$ \\
\hline Pseudomonas King's Medium A & Atlas \& Parks, 1993 & Proteose Peptone, Glycerol & + & - & \\
\hline Pseudomonas Denitrification & Atlas \& Parks, 1993 & Glycerol, Yeast Extract & + & - & \\
\hline $\mathrm{Bg}-11$ & Atlas \& Parks, 1993 & Citric acid, Ferric Ammonium Citrate & + & - & \\
\hline
\end{tabular}




\section{Microbial Quantification}

A very simple approach was taken to assessing overall abundance of culturable microorganisms. They were quantified using two techniques: serial dilutions with plate counts for viable culturable microorganisms and epifluorescence for total microbial enumeration of visible microbial bodies.

Serial dilutions were made for each sample with sterilized $0.1 \%$ sodium pyrophosphate solution $\left(\mathrm{Na}_{4} \mathrm{P}_{2} \mathrm{O}_{7}\right)$ as the dispersant. R2A, Variant 3 (a calcium succinate medium), and Hyphomicrobium media were used for plate count inoculation for comparisons to other environments. The latter two media were used because organisms grown on them rapidly produce significant visible mineralization. Uninoculated buffer and media controls were also utilized. Samples were incubated at $25^{\circ} \mathrm{C}$ for one week. After this incubation period, the number of visible colonies was quantified. Other characteristics were noted such as degree of mineralization. Bacterial and fungal presence was also noted based on examination with light microscopy.

Samples for total microbial enumeration included moonmilk, cottonballs and pool waters (Pool B and C). The LIVE/DEAD ${ }^{R}$ BacLight ${ }^{\mathrm{TM}}$ Bacterial Viability Kit for microscopy and quantitative assays (Invitrogen No. L7012) was used. Samples were analyzed within one hour after preparation with an Omega Chroma filter set on a Zeiss epifluorescence microscope. For each sample, thirty fields were randomly selected and counted. Microbial quantification was calculated using the method from Kepner \& Pratt (1994).

\section{Microscopy}

Scanning electron microscopy (SEM) coupled with EDS was used for high resolution imaging of the natural deposits for the presence of cells, filaments, biofilm, microstructural crystal morphologies, mineral composition, and then association of microorganisms and crystals within cultures.

For each deposit, one sample was untreated and the other fixed in situ with $2.5 \%$ filtered gluteraldehyde. Untreated samples were adhered to an aluminum SEM stub in the field. In the lab, samples to be fixed were subjected to a series of increasing ethanol solutions, finishing with $100 \%$ anhydrous ethanol for dehydration, followed by a series of ethanol: hexamethyldisilazane (HMDS) solutions before airdrying (Dekker et al., 1991).

For crystal-producing cultures, media plugs of interest were aseptically excised and mounted on an aluminum SEM stub with carbon tape. Samples were slowly dried and vacuum-pumped for $1 / 2$ hour prior to coating and analysis.

Samples were analyzed at the University of New Mexico Scanning Electron Microscope Laboratory using a JEOL 5800LV SEM coupled with secondary and backscattered electron and cathodoluminscence imaging detectors. The microscope is equipped with an Oxford Analytical ultra thin-window Energy Dispersive X-ray Spectrometer and an Oxford Isis 300 $\mathrm{X}$-ray analyzer. The SEM was operated at $10-15 \mathrm{kV}$ and a beam current between 0.25 and $1 \mathrm{nA}$. Samples were analyzed under high or low vacuum depending on charging severity. Samples were initially sputter coated with $22 \mathrm{~nm}$ of gold-palladium to provide conductivity under the electron beam. However, due to the friable nature of the samples, the conductive coating sometimes failed to provide sufficient conductivity; in these cases, samples were imaged in low vacuum, which often results in a loss of image resolution.

\section{Geochemical Methods}

\section{Inorganic Carbon/Organic Carbon}

Inorganic and organic carbon of mineral deposits and host rock were analyzed at New Mexico Tech Chemistry Department with a Shimadzu TOC 5000 Carbon analyzer. A combustion/non-dispersive infrared gas analysis method was used to measure total and inorganic carbon.

For inorganic carbon, $10 \mathrm{mg}$ of sample was treated with $0.5 \mathrm{ml}$ of $1 \mathrm{M}$ phosphoric acid $\left(\mathrm{H}_{3} \mathrm{PO}_{4}\right)$ immediately before combustion at $200^{\circ} \mathrm{C}$. Sodium bicarbonate $\left(\mathrm{NaHCO}_{3}\right)$ was used for the inorganic standard. Organic carbon was measured by first subjecting $100 \mathrm{mg}$ of each carbonate sample to multiple cycles of $5.0 \%$ phosphoric acid $\left(\mathrm{H}_{3} \mathrm{PO}_{4}\right)$ and dried at $100^{\circ} \mathrm{C}$ until effervescent reactions ceased. This procedure eliminated any inorganic carbon and left only organic carbon to be analyzed. The samples were then subjected to the total carbon (TOC) analyzer and combusted at $900^{\circ} \mathrm{C}$. Glucose $\left(\mathrm{C}_{6} \mathrm{H}_{12} \mathrm{O}_{6}\right)$ was used for the organic carbon standard. Duplicates were run for both inorganic and organic carbon analyses.

\section{$X$-Ray Diffraction}

Moonmilk water content was obtained during X-ray diffraction (XRD) preparation. Samples were preweighed for their wet weight and then reweighed after drying at $40^{\circ} \mathrm{C}$. Powdered samples of the deposits and host rock were analyzed at the XRD Laboratory in the Department of Earth and Planetary Sciences at the University of New Mexico, using a Scintag Pad $\mathrm{V}$ diffractometer with DataScan 4 software (MDI, Inc.) for system automation and data collection. $\mathrm{Cu}-$ $\mathrm{K} \_$a radiation radiation $(40 \mathrm{kV}, 35 \mathrm{~mA})$ was used with a Bicron Scintillation detector with a pyrolitic graphite curved crystal monochromator. Data were analyzed with Jade Software (MDI, Inc.) using the ICDD (International Center for Diffraction Data) PDF4 database (rev. 2006) for phase identification.

\section{Isotopic analyses}

Stable isotope methods were utilized in order to investigate possible abiotic or biological influences on carbon and examine the carbon and oxygen relationship between the host rock and deposits as revealed by isotopic fractionation. The solid fractions of moonmilk, cottonballs, and host rock were analyzed for $\delta^{18} \mathrm{O}$ and $\delta^{13} \mathrm{C}$. Triplicates were run for all the solid fraction samples collected. Carbonate samples were treated with $100 \% \mathrm{H}_{3} \mathrm{PO}_{4}$ (phosphoric acid) and 
subsequently heated for three hours at $45^{\circ} \mathrm{C}$ prior to analysis. For organic carbon analysis, the carbonate deposits and soils were repeatedly acidified with $10 \%$ $\mathrm{HCl}$ and subsequently dried at $50^{\circ} \mathrm{C}$. Leaf litter, soil, and both carbonate deposits were analyzed for organic carbon. Duplicates were run for all the organic carbon samples. Stable isotope data were reported in per mil (\%o) relative to Pee-Dee Belemnite (PDB).

For present pool waters within the cave, $\delta D$ and $\delta^{18} \mathrm{O}$ were analyzed to better understand the fractionation of the present meteoric waters $\delta^{18} \mathrm{O}$ values in relation to the $\delta^{18} \mathrm{O}$ of the moonmilk and cottonball deposits. Stable isotope data for waters were reported in per mil $(\%)$ relative difference to Standard Mean Ocean Water (SMOW) and later converted to Pee-Dee Belemnite (PDB) for $\delta^{18} \mathrm{O}$. All analyses were made on a Thermo Finnigan Delta Plus XP in continuous flow mode except for $\delta D$, which was measured in dual inlet mode.

\section{RESULTS}

\section{Geomicrobiology}

\section{Cultivation}

Cultures from both deposits yielded visible growth for common soil microflora groups: fungi, bacteria, and actinomycete bacteria, from tests defined by Garrett (1963). However, no cyanobacteria or eukaryotic algae were cultivated. Selective media yielded positive growth for common culturable soil bacteria such as Pseudomonas (Maier et al., 2000) and other heterotrophic soil bacteria, Actinobacteria and Hyphomicrobium, although these designations are putative and not definitive. Growth on complex media indicated the presence of heterotrophic aerobic or possibly facultatively aerobic microorganisms (Table 2). Due to the selection of media chosen for crystallization experiments, the main culturable microorganisms obtained were heterotrophic filamentous bacteria and fungi. However, the dominant culturable microorganisms within the cottonball cultures were biofilm-producing bacterial colonies, which produced significant crystallization.

\section{Isolation}

In cultures from both deposit types, calcite crystallization occurred in the following media: Hyphomicrobium, Variant 2, and Variant 3. For both deposits, Hyphomicrobium Medium-grown colonies displayed unusual " $x$ " shaped crystals after seven months of growth. Precise mineralogical composition of these crystals requires further XRD studies.

Greater production of crystals, quicker crystalline growth rates, and calcitic mineralogical composition of the crystal deposits were observed in Variant 3 medium for the cottonballs. After seven days of growth, millimeter-sized calcite crystals appeared within light tan, raised, irregular to lobate, opaque colonies that formed on the surface of Variant 3 medium (Figure 6). Variant 2 media yielded similar calcitic crystal precipitation and colony characteristics for both the moonmilk and cottonball deposits. This calcitic crystallization was only observable at the microscopic level. Crystal morphology was rhombic to anhedral "snowflake" shapes. SEM images revealed smaller crystals $(100 \mu \mathrm{m})$ near the larger more centrally located crystals within the biofilm. Cellular bodies were less evident around the larger crystals; however, they were more visible and abundant within the vicinity of smaller crystals (Figure 7). EDS confirmed that the chemical composition of the crystals was carbon, oxygen, and calcium, thereby suggesting a likely carbonate mineralogy.

\section{Microbial Quantification}

Table 2 shows the results of the microbial quantification for the various media. For the cottonballs, the preferred substrate was Hyphomicrobium Medium, followed by Variant 3 medium; the least growth occurred with R2A medium. Moonmilk cultures displayed an opposite trend, and for these samples, microbial growth was best on R2A, followed by Variant 3 and then Hyphomicrobium Medium. Viable plate counts for both deposits were considerably less when compared to average soil, e.g. typically $3.5 \times 10^{5} \mathrm{CFU} / \mathrm{g}$ (Maier et al., 2000). The average viable cell count for the cottonballs was $4.4 \times 10^{4} \mathrm{CFU} / \mathrm{g}$ and for moonmilk was $3.6 \times 10^{4} \mathrm{CFU} / \mathrm{g}$.

The total undifferentiated microbial count for moonmilk and cottonballs was $4.9 \times 10^{6}$ and $1.3 \times 10^{6}$ $\mathrm{CFU} / \mathrm{g}$, respectively. The pool water total bacterial count was significantly lower at $5.3 \times 10^{5} \mathrm{CFU} / \mathrm{ml}$ for Pool B and $1.5 \times 10^{5} \mathrm{CFU} / \mathrm{ml}$ for Pool C. We used this broad brush metric as an overall screening technique to gain some insight into the relative biological activity within the materials rather than trying to identify specific strains.

\section{Microscopy}

In situ Samples: Microstructure Crystalline Morphology.

Both the cottonballs and moonmilk consisted of aggregates of randomly oriented microcrystalline needle-fiber calcite crystals and substantial filamentous material. Examination of cottonball SEM images showed that needles ranged from 1 to $24 \mu \mathrm{m}$ in width and 30 to $267 \mu \mathrm{m}$ in length. The needle fibers consisted of three morphological subdivisions as used by Verrecchia \& Verrecchia (1994); monocrystalline, coupled monocrystalline, and serrated-edge rods (from least to most complex). The aggregate was mainly comprised of monocrystalline needles (1-3 $\mu \mathrm{m}$ wide, $30-267 \mu \mathrm{m}$ in length) and to a lesser extent composed of nano-fibers $(\leq 1 \mu \mathrm{m})$ and polycrystalline needles (6-24 $\mu \mathrm{m}$ wide and 45-126 $\mu \mathrm{m}$ in length), shown in Figure 8. Interestingly, the monocrystalline needles are actually an inner rod usually $2 \mu \mathrm{m}$ in diameter coated by an outer layer (Figure 8f). The outer layer may represent recrystallization or additional deposition around an initial central rod or filament. Abundant nanometer-sized filaments were present, draped on needles, and within the interstitial spaces. Figure 9e illustrates a filament that has not been completely encrusted. Instead, one can see the transition from the filament to the encrusted calcite end of the filament. Cottonballs in Pool B displayed 


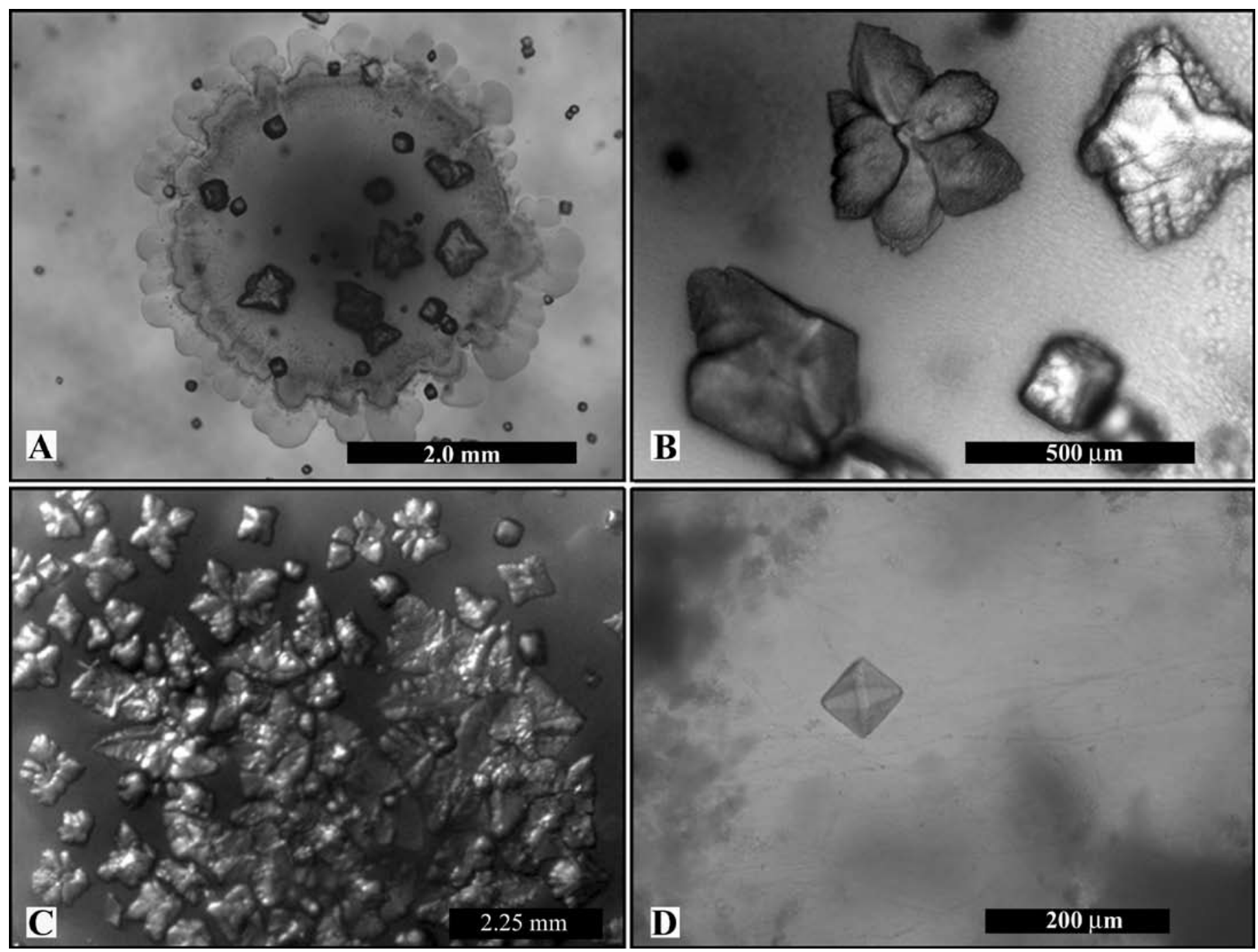

Fig. 6. Calcite crystallization observed within cottonball Variant 3 media cultures after (C) 14 days and (A, B, and D) 117 days of growth. (A) through $(C)$ shows the typical snowflake-like crystallization observed within biofilms of colonies on the surface of the media. Photo $D$ shows a euhedral calcite dipyramidal crystal in close proximity to filaments within the Variant 3 medium.

what appears to be a filamentous mat. Upon closer inspection, the filamentous mat was comprised of yet finer nanometer-sized needles (Figure 8d). The polycrystalline needles were composed of stacked calcite rhombohedra with the $\mathrm{c}$ axis perpendicular to the needle length giving the morphology an en echelon appearance (Verrecchia \& Verrecchia, 1994).

Similar to the cottonballs, the moonmilk was an aggregate comprised of randomly orientated calcitic fibrous needles with the same morphologies (i.e., monocrystalline, polycrystalline, and filaments), illustrated in Figure 9. However, polycrystalline needles were the dominant crystal morphology, the inverse of the cottonball case (Figure $9 \mathrm{c}-\mathrm{f}$ ). Significant branching filaments and filamentous mats were also present in the moonmilk crystalline aggregate although the locations of the mats were random and not uniformly distributed throughout the deposit. The polycrystalline needles in the moonmilk displayed a broader width compared to the cottonballs. Due to a higher abundance of these polycrystalline needles, moonmilk provided a more rigid framework when compared to the fragile elongated monocrystalline needles of the cottonballs.

\section{Geochemistry}

The moonmilk within Cataract Cave appears to be a fairly well-hydrated deposit. The water content was 63.8 wt.\%, which compares well with other hydrated moonmilk deposits (e.g., 70 wt.\%, Bernasconi, 1976; >58 wt.\%, Onac, 1995; furry moonmilk, 71-75 wt.\%, Gradziñski et al., 1997). The cottonball deposits are fully submerged in the pool waters; thus, the pore spaces within the deposit are completely saturated, in which the pool water acts as a buoyant structural support. However, the cottonball water content (85-94 wt.\%) is comparable to a particularly moist subaerial felt-moonmilk reported by Gradziñski et al. (1997).

Moonmilk displayed a higher abundance of organic carbon $(\mathrm{OC}=0.20 \mathrm{wt} \%)$ compared to the cottonballs (0.12 wt.\% OC) and host rock (0.04 wt.\% OC). Inorganic carbon values (IC) were similar among the three; moonmilk 10.0 wt.\% IC, cottonballs 10.1 wt.\% IC, and the Heceta Limestone host rock 10.9 wt.\% IC. This is to be expected due to the mineralogical composition being calcite $\left(\mathrm{CaCO}_{3}\right)$ with maximum IC being 12 wt.\%. Bulk XRD analyses for both the cottonballs and moonmilk contained single-phase matches for calcite; no other phases or peaks were evident. Peak identification for the host rock (Heceta 

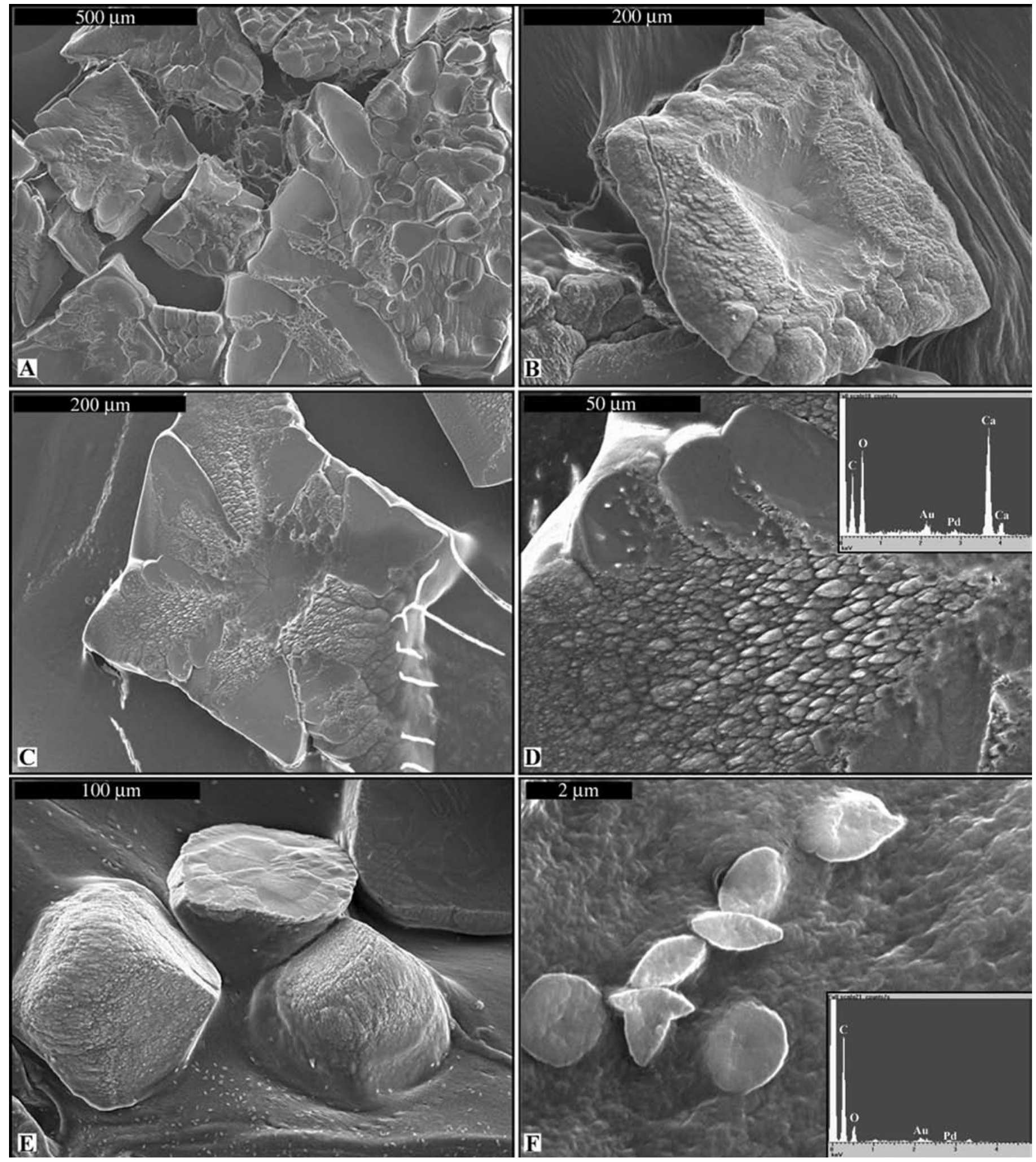

Fig. 7. SEM photomicrographs of the snowflake-like crystallization and microbial bodies observed in cottonball Variant 3 (calcium succinate) media cultures after 117 days of growth. For the samples, crystallization occurred on the media surface within biofilm. Under SEM, cellular bodies were not observed in association with the larger crystals (A-D). However, the presence of cellular bodies were observed on and in close proximity to the smaller more rhombic calcite crystals ( $E$ and $F$ ). This association may suggest that the cells or macromolecules within the biofilm may act as a passive nucleation site. For photomicrograph (D), the EDS results for crystal composition are provided in the upper right hand corner inset. In addition, this photomicrograph shows further detail of the crystal growth and texture associated with the larger crystals. For photomicrograph (F), an EDS spectrum of the cellular bodies composition is provided in the lower right hand corner inset. This photomicrograph also provides a closer image of the cells in (E).

Limestone) was well matched with calcite and minor traces of quartz.

Stable isotopic analysis of carbon revealed a significant difference between the host rock, moonmilk and cottonballs (Table 3$)$. The host rock value $\left(\delta^{13} \mathrm{C}=\right.$ $+1.1 \%$ ) was typical for a marine carbonate (Hoeffs, 2004) and was isotopically heavier than both the cottonballs $\left(\delta^{13} \mathrm{C}=-8.1 \%\right.$ ) and the moonmilk $\left(\delta^{13} \mathrm{C}\right.$ 

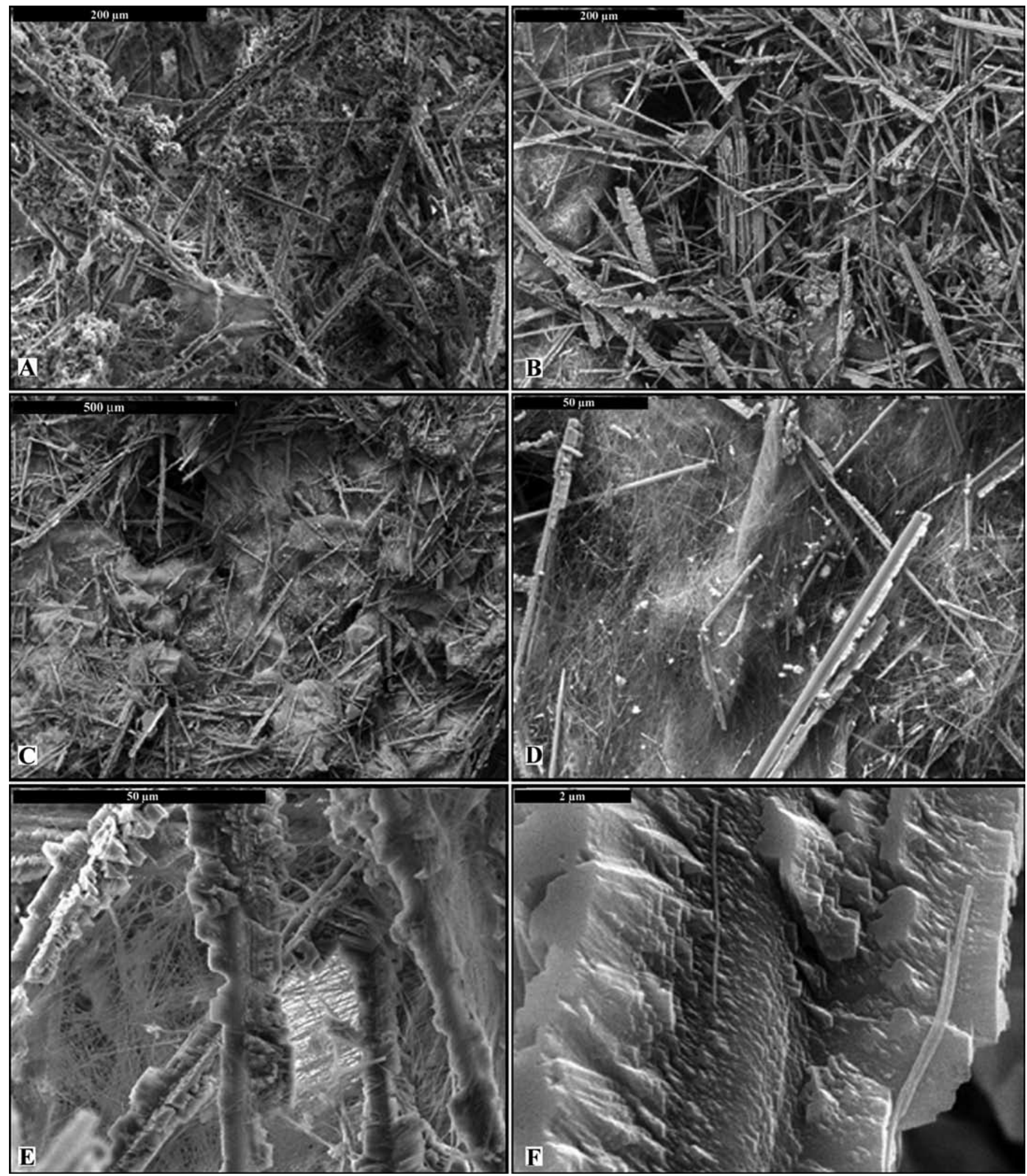

Fig. 8. SEM photomicrographs showing the monocrystalline dominated needle-fiber calcite crystal morphologies observed within the cottonball deposits. (A) Overview of the monocrystalline needle-fiber calcite filaments with common occurrence of intertwined with needles in the foreground. (B) Monocrystalline needle-fiber calcite and serrated-edge monocrystalline needle morphologies that are thought to represent post-depositional physicochemical precipitation processes. The left side and foreground exhibits the fibrous mats underlying the needle-fiber calcite. (C) Mesh and incorporation of some of the needle-fiber calcite within the nano-fiber mat. This photomicrograph provides an overview of the dense, nano-fiber mat commonly found throughout the deposit. Mats may represent dense microbial mats or biofilms within the deposits. Also note the appearance of serrated-edge monocrystalline rods and lack of polycrystalline morphologies within the deposit. (D) Closer view of the dense, fine mesh of nanofiber mats in C. (E) Extensive network of the larger filaments seen throughout the deposit, intertwining and bridging pores among the serrated needle-fiber calcite, and, thus, possibly providing a biological structural support for the deposit. (F) Image showing the inner rod and a secondary outer crystallization component with a nano-fiber on the inner rod and a draped filament on outer coating on the right-hand side. 

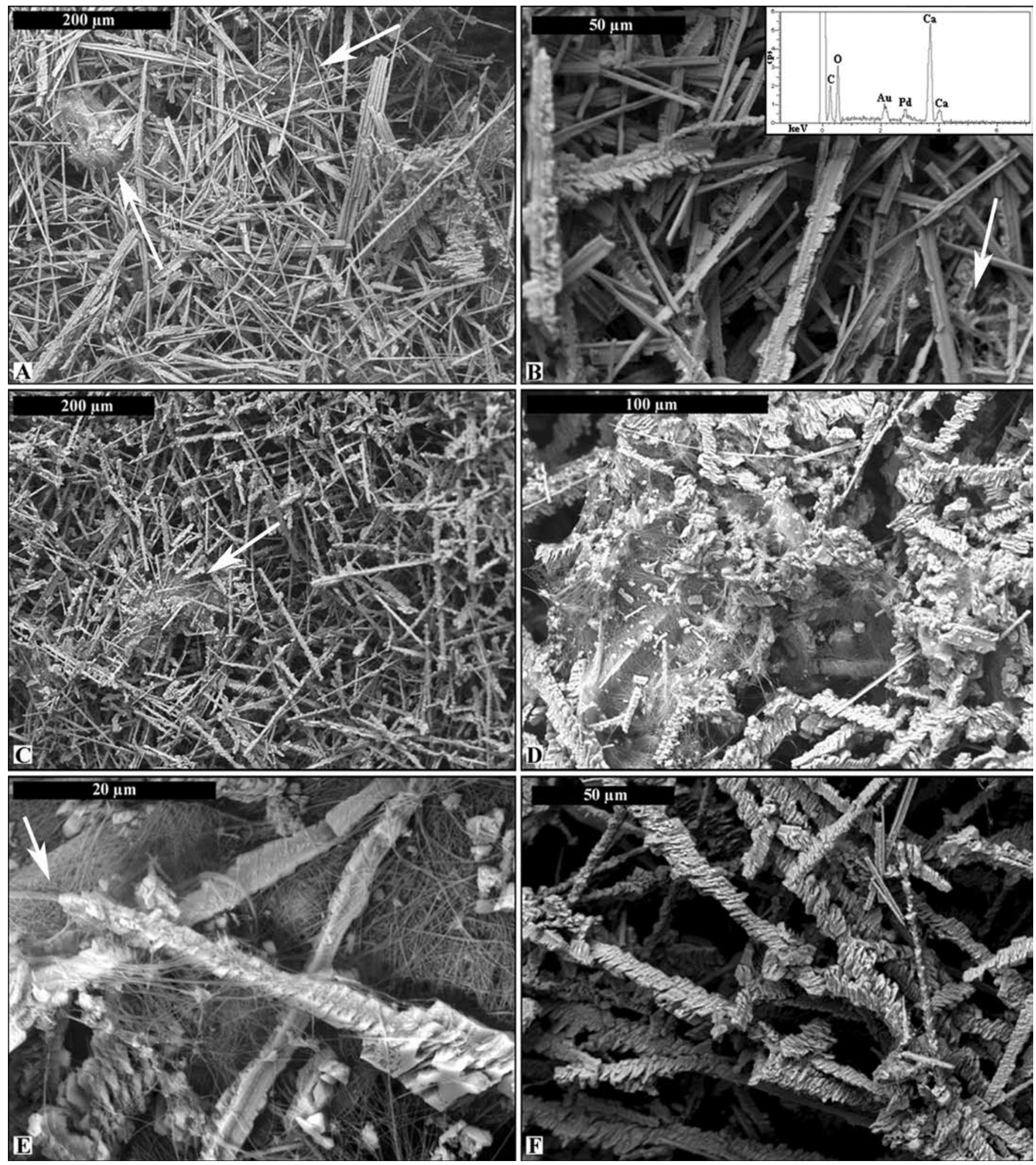

Fig. 9. SEM photomicrographs of the calcite crystal forms observed within the moonmilk deposit. (A) Overview of the monocrystalline, serratededge, bundling, and some polycrystalline needle-fiber calcite associated with the moonmilk. Arrows indicate areas with dense filaments occlude the pore spaces and intertwining around the needle-fiber calcite. (B) Various versions of the serrated monocrystalline needle-fiber calcite. Inset displays the EDS results from the crystals mineralogical composition. Gold and palladium are from the sample preparation sputter coating. Arrow indicates area of filaments bridging between needles. (C) Overview of the mesh of the polycrystalline needle-fiber calcite associated with the moonmilk deposit, which are not seen in the cottonball deposit. Arrow points toward dense area of filament growth. Note that the polycrystalline needle-fibers start to become shorter and wider compared to the monocrystalline needle morphologies. (D) This photomicrograph reveals the growth of a dense filamentous mat that is seen in $C$. Note that fibrous growth occurs with both monocrystalline and polycrystalline needle-fiber calcite. (E) Draping and branching filamentous growth occurring in dense mats and bridging within the interstitial pores of the deposit. Arrow shows a filament that has been partially entombed by extensive precipitation. (F) Section of moonmilk dominated by polycrystalline needle-fiber calcite. Note the absence of filaments or mats. Filaments, mats, and nano-fibers can be found within the polycrystalline needle-fiber calcite; however, these biological features are more abundant and common with monocrystalline morphologies. Polycrystalline needle-fibers have been suggested as possible diagenetic morphologies due to this lack of biological features. 
$=-1.6 \%$ o). The carbon signatures for the soil organic carbon and leaf litter from the surface were isotopically light $\left(\delta^{13} \mathrm{C}=-24.3\right.$ and $-25.4 \%$, respectively $)$ as expected for organic matter and C3 vegetation (Sharp, 2007). However, the organic carbon signatures from both the moonmilk and cottonballs were isotopically lighter $\left(\delta^{13} \mathrm{C}=-27.4\right.$ and $-26.7 \%$, respectively $)$ compared to the soil organic carbon and leaf litter.

The oxygen signatures of the host rock, moonmilk, and cottonballs are similar and appear to be roughly in equilibrium with the pool waters. For the pool waters, the $\delta \mathrm{D}$ values ranged between -85 to $-87 \%$ o SMOW and $\delta^{18} \mathrm{O}$ ranged between -12 to -13 SMOW (Figure 10B).

The measured fractionation value $\left(\delta^{18} \mathrm{O}_{\text {calcite }}-\delta^{18} \mathrm{O}_{\text {water }}\right.$ $\approx 1000$ ln $\left.\mathrm{a}_{\text {calcite-water }}\right)$ of the combined water and cottonball material is $34.5 \%$. The combined value for water and moonmilk is $35.1 \%$. The calculated fractionation of combined calcite and water in equilibrium at low temperatures, using the equations by O'Neil et al. (1969) and Friedman \& O'Neil (1977) and the measured pool temperatures, at $7^{\circ} \mathrm{C}$ is $32.5 \%$ o for the cottonballs and at $4.4^{\circ} \mathrm{C}$ is $33.2 \%$ or the moonmilk. The $\delta^{18} \mathrm{O}$ values of the calcite deposits $(\sim 2 \%)$ are close to equilibrium with the water (Table 4).

\section{DISCUSSION}

\section{Calcite Precipitation}

One of the unusual features of the cottonballs is precipitation occuring at the bottom of the pools at the rock-water interface and not at the air-water interface as is found with simple, abiologically precipitated calcite rafts. These structures are loose on the bottom of the pool and crystal growth radiates outward from their centers. Thus, they do not resemble in any way the sunken piles of rafts that make up so many residual pool and paleopool deposits. SEM imaging of our samples showed that there was no accumulation of broken calcite raft crystals within the aggregate as compared morphologically with a raft study by Taylor \& Chafetz (2004). In cross section at macroscopic

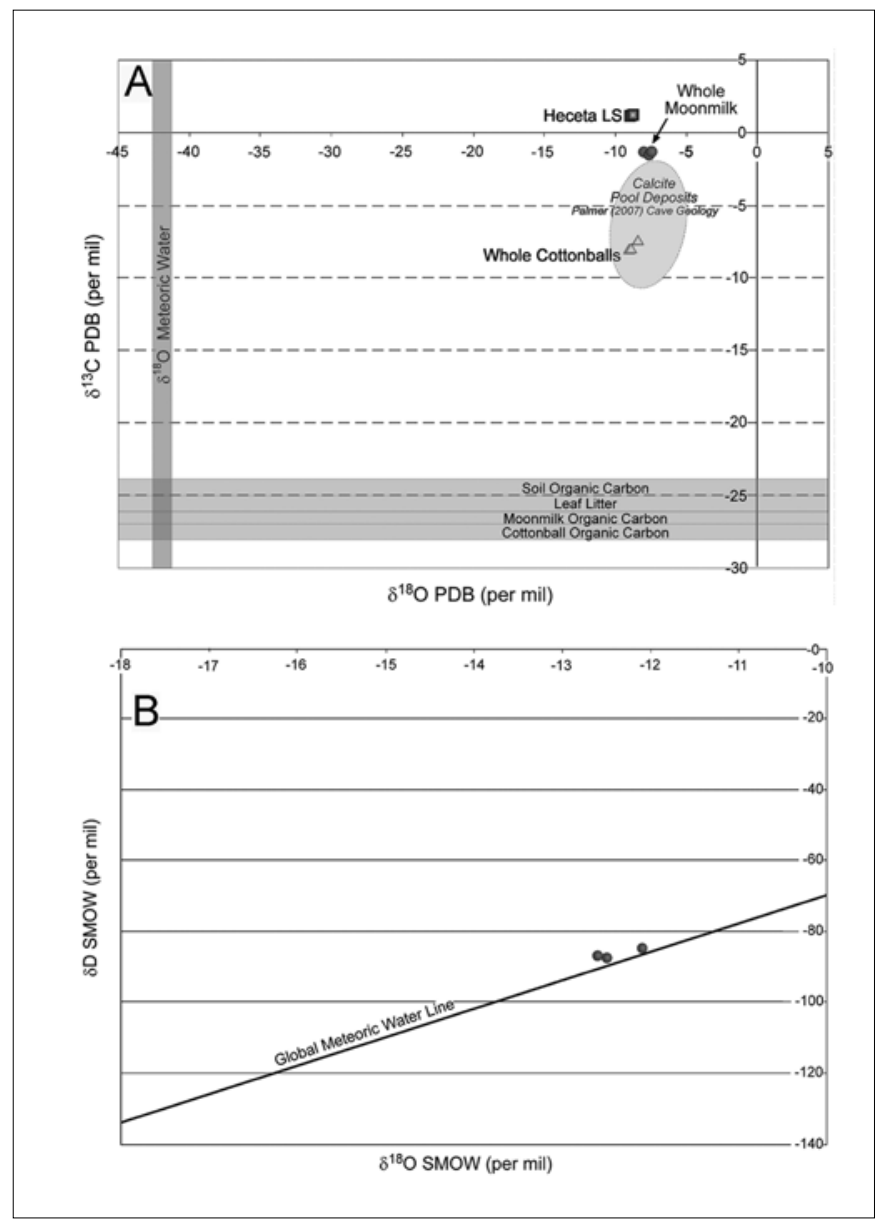

Fig. 10. (A) $\delta 13 \mathrm{C}$ and $\delta 180$ plot showing the oxygen and carbon isotopic relationship among the cottonballs, moonmilk, host rock and organic carbon signatures. Note that for organic carbon, only the carbon signature is analyzed while for the pool waters, only the oxygen isotopic signature was analyzed. The gray elliptical area represents the typical calcite pool deposits (values from Palmer, 2007). (B) $\delta D$ and $\delta 180$ plot showing the pool waters in relation to the global meteoric water line.

scale, some cottonballs even appear to have evidence of slight banding that might represent different periods of growth, similar to those of flowstone, but less visually obvious (Figure 4). This could indicate possible variability in water chemistry or precipitation

Table 3. Compilation of the average geochemical and microbiological results for the cottonballs, moonmilk, and host rock.

\begin{tabular}{|c|c|c|c|}
\hline & Cottonball & Moonmilk & Host Rock \\
\hline Wt.\% inorganic C & 9.80 & 9.95 & 10.6 \\
\hline Wt.\% organic C & 0.143 & 0.203 & 0.0435 \\
\hline$\delta^{13} \mathrm{C}_{\text {carbonate }}(\%$, PDB) & -7.8 & -1.6 & +1.1 \\
\hline$\delta^{18} \mathrm{C}_{\text {carbonate }}(\%$, PDB) & -8.7 & -7.6 & -8.8 \\
\hline$\delta^{13} \mathrm{C}_{\text {organic fraction }}(\%$, PDB) & -26.7 & -27.4 & \\
\hline Water Content Wt. $\%$ & $85-94$ & 64 & \\
\hline Viable Culturable Microorganisms (CFU/g) & $4.40 \times 10^{4}$ & $3.56 \times 10^{4}$ & \\
\hline Total Microbial Enumeration (CFU/g) & $1.30 \times 10^{6}$ & $4.85 \times 10^{6}$ & \\
\hline
\end{tabular}

Table 4.Measured and calculated isotopic fractionation values of the pool water and deposits. The calculated fractionation of combined calcite and water in equilibrium at low temperatures, using the equations by O'Neil et al. (1969) and Friedman \& O'Neil (1977).818O values are in \%o with respect to VSMOW.

\begin{tabular}{|c|c|c|c|}
\hline & Measured & Calculated & Temperature (oC) \\
\hline Water and Cottonballs & 34.5 & 32.5 & 7.0 \\
\hline Water and Moonmilk & 35.1 & 33.2 & 4.4 \\
\hline
\end{tabular}


rates or episodicity. In addition, the cottonball fabric is a fragile structure composed mainly of monocrystalline rods, and biofilaments with a great deal of water-filled space. In fact, the three dimensional structure of the cottonballs is dependent upon immersion in the water, much as delicate sea creatures like jellyfish who lose all structural integrity when removed from their fluid environment. Therefore, fluid input into the pool must occur at a slow enough rate that it will not mechanically disturb the delicate structures. Thus, the overall structural integrity of the cottonballs is only partly dependent upon the intermeshing of the filaments and crystals.

Both, the moonmilk and cottonballs are composed of aggregates of a calcite microcrystalline habit known as needle-fiber calcite. This calcite crystal morphology is associated with vadose zone and soil calcretes (e.g., Verrecchia \& Verrecchia, 1994; Cañaveras et al., 2006). Furthermore, needle-fiber morphologies and filaments have been reported from a number of other moonmilk deposits (e.g., Shumenko \& Olimpiev, 1977; Onac \& Ghergari, 1993; Gradziñski et al., 1997; Cañaveras et al., 1999; Borsato et al., 2000; Chirienco, 2002; Lacelle et al., 2004; Cañaveras et al., 2006). Current studies associate needle-fiber calcite as a type of organomineral, or biologicallyinfluenced mineralization products (Verrecchia et al., 1993; Verrecchia \& Verrecchia, 1994; Gradziñski et al., 1997; Bajnóczi \& Kovács-Kis, 2006; Dupraz et al., 2008) via passive mineralization, such as nucleation on cell walls, filaments, organic matter, or on macromolecules within biofilms.

Both the moonmilk and cottonballs display significant numbers of biological filaments dispersed throughout the interstitial pore spaces and what appears to be nano-fiber microbial mats. The dimensions of the filaments $(>2 \mu \mathrm{m})$ are comparable to fungal hyphae, however, the nano-fibers are more similar in size to bacterial filaments $(\geq 1 \mu \mathrm{m}$; Wilkinson, 2003). The presence of possible branching fungal hyphae, microbial filamentous mats, and positive growth results from cultures all indicate that active metabolism is present within the deposits. The width of the monocrystalline needle-fibers are also comparable to microbial dimensions, which may suggest passive nucleation.

Both the cottonball pools and moonmilk experience the same favorable chemical conditions for calcite $\left(\mathrm{CaCO}_{3}\right)$ precipitation, namely, buffered neutral to alkaline environment and a continuous source of $\mathrm{Ca}^{2+}$ ions (Ehrlich, 1996). Possible influences on the $\mathrm{CaCO}_{3}$ precipitation could include the colder temperatures which increases the $\mathrm{CO}_{2}$ solubility (Garrels \& Christ, 1965; Langmuir, 1997; Ford \& Williams, 2007). The presence of heterotrophs and other microbial metabolism activities may alter the alkalinity (Ercole et al., 2001; Dupraz et al., 2008). No evidence of dissolution or fungal boring at the microscopic scale was seen.

In general, mineralogy and crystal shape is a function of the environment in which precipitation occurs (Ercole et al., 2001; Dove et al., 2003). This may include extrinsic factors such as physiochemical processes, and intrinsic microbial processes, such as respiration or production of organic molecules (Dupraz et al., 2008). Both deposits exhibit similar but distinguishable needle-fiber calcite morphologies. However, from field observations, each deposit has been precipitated in a completely different environment, one subaqueous and the other subaerial. This agrees with Verrecchia \& Verrecchia (1994) who wrote that comparable needle-fiber morphologies are plausible, however, appear not to be genetically related (in the mineralogical sense of the term). This suggests that the definition for moonmilk may properly encompass many characteristics. Alternatively, these variations within the main needle morphology (monocrystalline versus polycrystalline) may or may not indicate differentiation between dominant mechanisms that are responsible for precipitation. For example, the significant presence of polycrystalline morphologies within the moonmilk may be attributed to the depositional environment, in which the moonmilk is subjected to further physicochemical or diagenetic processes (e.g., degassing, evaporation, temperature fluxes, dissolution, or physical breakdown; Jones \& Kahle, 1993). However, one or more mechanisms may overlap, thus producing similar macroscopic appearances.

\section{Isotopic Origins and Possible Influential Processes}

The pool water values plot on the global meteoric water line (GMWL). There appears to be no significant evaporation of the pool water unless the relative humidity within the cave is high, in which case evaporation will change both $\delta^{18} \mathrm{O}$ and $\delta \mathrm{D}$ along the GMWL line with the slope of 8 (Figure 10B). Additional seasonal isotopic analyses and environmental measurements are needed to further clarify the evaporation rates. The overlying surface environment for Cataract Cave has predominantly $\mathrm{C} 3$ vegetation and the $\delta^{13} \mathrm{C}$ values of the soil and leaf litter organic carbon are consistant with $\mathrm{C} 3$ vegetation values (Sharp, 2007). Thus, we can infer that the overlying vegetation and organic carbon, such as organic acids, are carried into the cave by meteoric seepage water. This seepage dissolves the surrounding limestone host rock and the ${ }^{13} \mathrm{C}$ from this limestone becomes incorporated into the infiltrating meteoric solution. Therefore, the solution contains ${ }^{13} \mathrm{C}$ from the overlying vegetation, organic sources, and $\mathrm{HCO}_{3}^{-}$from the host rock. Another probable ${ }^{13} \mathrm{C}$ source is soil biogenic $\mathrm{CO}_{2}$, however, this was not measured directly in this study.

The close approach to equilibrium values between water and calcite $\delta^{18} \mathrm{O}$ values (Table 4) is a likely indicator of equilibrium deposition, in which the rate of loss of $\mathrm{CO}_{2}$ from solution is slow (Hendy, 1971). A greater degree of difference in the values would be expected for kinetic deposition, in which loss of $\mathrm{CO}_{2}$ from solution is rapid (Hendy, 1971). In addition, highhumidity levels are characteristic of cold temperate region caves, which minimizes evaporation and kinetic isotopic fractionation (McDermott, 2004). 
As can be seen from Figure 10A, the cottonball $\delta^{13} \mathrm{C}$ value is $6.2 \%$ o lighter than the moonmilk $\delta^{13} \mathrm{C}$ value and they exhibit the characteristic isotopic values for pool deposits (Palmer, 2007) but the moonmilk values are heavier. The cottonball $\delta^{13} \mathrm{C}$ values are consistent with other pool deposits, falling between the cave atmosphere $\mathrm{CO}_{2}$ and host rock. This interpretation neglects other possible processes like microorganism metabolism.

The drop in $\mathrm{P}_{\mathrm{CO} 2}$ from the soil to the cave air causes degassing of $\mathrm{CO}_{2}$ from solution, resulting in calcite supersaturation and subsequent precipitation a classical physicochemical process of speleothem formation (Hendy, 1971; Mickler et al., 2006). The pool deposits are stagnant shallow bodies of water whose minimal surface area will degas $\mathrm{CO}_{2}$ only at the waterair surface (Palmer, 2007). This equilibrium between the cave $\mathrm{CO}_{2}$ and pool reservoir will create isotopic values closer to the cave atmospheric $\mathrm{CO}_{2}$ (Palmer, 2007). This is reflected in the cottonball values and, thus, creates an isotopically lighter reservoir compared to thin water films associated with the moonmilk. In contrast, the moonmilk is deposited by seepage from rock walls. The chemically active area is at the rock and seepage interface; thus, it is potentially protected from rapid equilibrium with cave air $\mathrm{CO}_{2}$ by the moonmilk already deposited. In addition, it is known that enhanced $\mathrm{CO}_{2}$ degassing in laminar thin film flow in combination with calcite precipitation creates an isotopically heavier ${ }^{13} \mathrm{C}$ reservoir (Fornaca-Rinaldi et al., 1968; Hendy, 1971; Mickler et al., 2006). Thus, enhanced degassing will create an enriched ${ }^{13} \mathrm{C}$ reservoir compared to the cottonballs. This increased $\mathrm{CO}_{2}$ degassing pulls the isotopic value of the moonmilk closer to that of the host rock (Figure 10A). Such $\delta^{13} \mathrm{C}$ relationships are also seen in other pool and subaerial deposits, such as flowstone (Palmer, 2007).

Despite the differences in depositional environment and overall $\delta^{13} \mathrm{C}$ values, the organic carbon $\delta^{13} \mathrm{C}$ values of the deposits are similar between cottonballs and moonmilk, and are considerably lighter compared to the overall, inorganic carbonate plus organic carbon values ( 15-20\% difference). In addition, they are both similar to the soil organic carbon and leaf litter. Therefore, we infer that the present biomass within the deposits comes from surface-derived organics and not from the $\mathrm{HCO}_{3}^{-}$present.

The moonmilk contains twice the percentage (wt\%) of organic carbon compared to the cottonballs (Table 3 ), so we would anticipate that the carbon isotopic values of the combined organic and inorganic moonmilk would be isotopically light. However, we

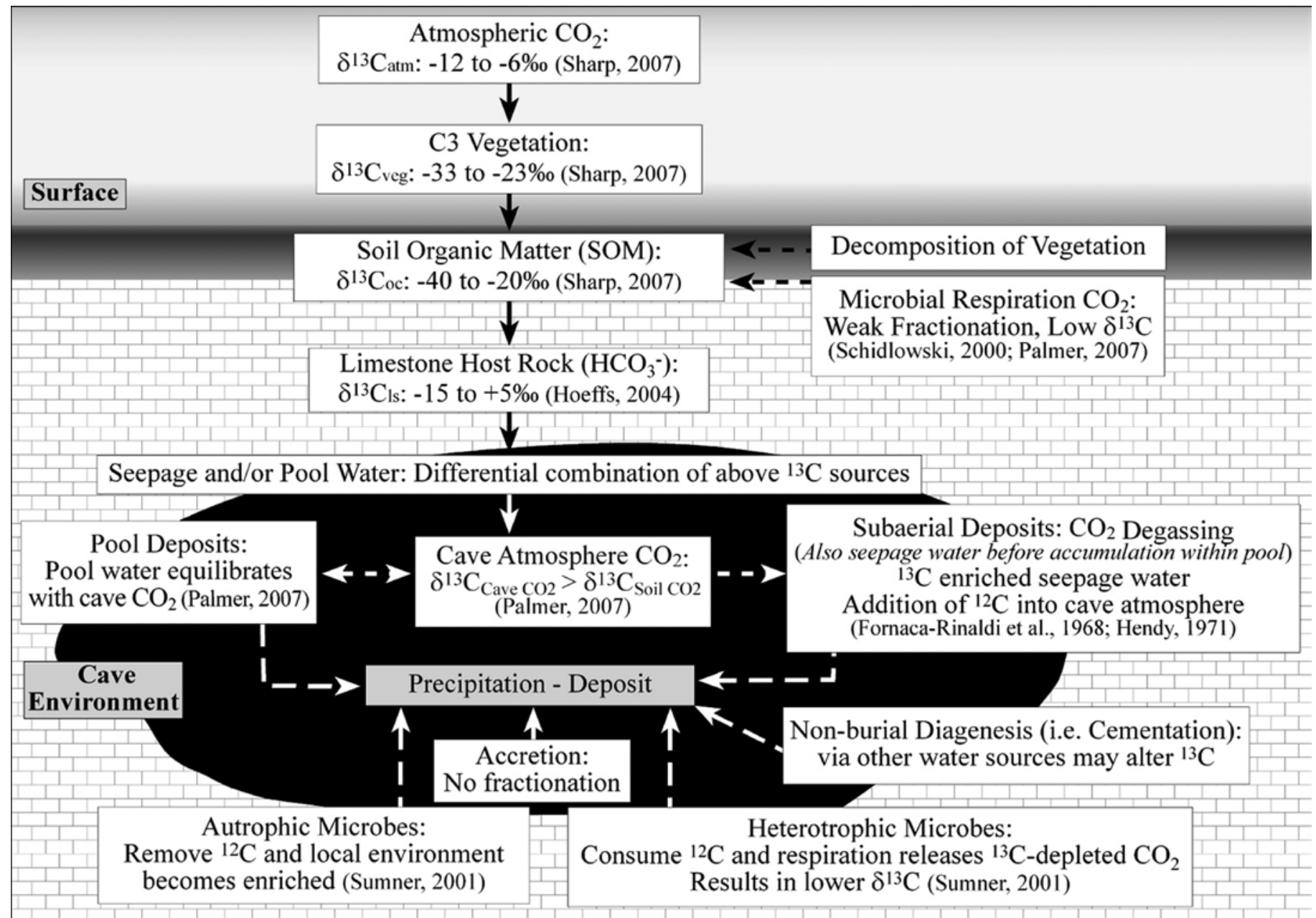

Figure 11. General diagram illustrating the various carbon components (solid arrows) and processes (dashed arrows) that influence the moonmilk and cottonball $\delta 13 \mathrm{C}$ signatures: starting with water infiltrating from the surface, continued seepage water through the near subsurface, and into the cave environment were equilibrium deposition occurs. Note that this a general diagram and $\delta 13 \mathrm{C}$ values vary with geological, geographic, and biological setting. Carbon values are in \%o with respect to PDB. Modified from Ford \& Williams (2007). 
see an opposite trend, namely the $\delta^{13} \mathrm{C}$ values of whole moonmilk (organic and inorganic) are heavier compared to the comparable cottonball $\delta^{13} \mathrm{C}$ values, which contain half the proportion of organic carbon. This isotopic enrichment in the heavy isotope may be attributable to the $\mathrm{CO}_{2}$ degassing mechanism discussed above. In contrast, the cottonball signature is significantly influenced by the pool $\mathrm{CO}_{2}$ equilibration with isotopically lighter cave atmosphere. However, this carbon distribution may also suggest a difference in microbial processes, structure, or activity rates between the pool and moonmilk. However, this study cannot distinguish between these hypotheses.

Verrecchia et al. (2003) showed some trends in their needle-fiber calcite isotopic data $\left(\delta^{13} \mathrm{C}\right.$ and $\left.\delta^{18} \mathrm{O}\right)$ but it was not correlated with environmental variables, ultimately leading to inconclusive results. This lack of clarity in the isotopic signatures may be the result of the complex nature of the various potential carbon sources available for formation of the calcite (Verrecchia et al., 2003). For example, in Cataract Cave, one plausible carbon source is the slightly isotopically heavy Heceta Limestone host rock $\left(\delta^{13} \mathrm{C}\right.$ $=+1.1 \%$ o). Figure 11 illustrates the possible carbon sources and processes that might influence the $\delta^{13} \mathrm{C}$ signature of the Cataract Cave moonmilk and cottonball deposits.

In summary, it appears that both Cataract Cave calcite deposits use the $\mathrm{HCO}_{3}{ }^{-}$in the solution derived from limestone dissolution. In contrast, the microbial communities utilize the organic sources in solution derived from leaching of soil and leaf litter. Despite the apparent different sources of carbon for microbes and minerals, the microbes may still play a role in calcite precipitation via passive nucleation (Danielli \& Edington, 1983; Northup \& Lavoie, 2001).

\section{Microbial Considerations}

Total microbial enumeration of natural and cultured carbonate deposits in this study are comparable to or higher than other studies (Table 2). Our culturable moonmilk populations were more abundant than culturable cell counts in a study by Mulec et al. (2002) from a moonmilk deposit from Snezna Jama Cave, Slovenia, where they reported $6.4 \times 10^{2} \mathrm{CFU} / \mathrm{ml}$ on Moonmilk Medium. From the same study, counts of pool samples with King B, prep medium and 0.1xNA medium from Pecina $\mathrm{v}$ Borstu Cave yielded 1.5$2.5 \times 10^{4} \mathrm{CFU} / \mathrm{ml}$ (Mulec et al., 2002). Total microbial counts for the moonmilk and cottonballs are likewise comparable to reported surface soil counts at a depth of $10 \mathrm{~cm}$. Maier et al. (2000) report $2.6 \times 10^{6}$ counts / gram compared to $4.9 \times 10^{6}$ and $1.3 \times 10^{6}$ cells / gram for our moonmilk and cottonballs.

Comparing our results to soils in the typical forest setting of POWI, we see comparable bacterial abundances between our cave deposits and Western Hemlock forest soils (Turner \& Franz, 1985). The deposits are located within the upper segment of the cave in close proximity to overlying soil horizons, which typically are dominated by heterotrophic microorganisms (Fierer \& Jackson, 2006). Therefore, the presence of heterotrophic bacteria within these cave deposits is to be expected and was confirmed. Other metabolism types are possible including various forms of chemolithotrophy but we did not conduct a search for these types of organisms because we were using total culturable abundance as a simple proxy for overall potential biogenicity of moonmilk. The presence of apparent fungi seen in cave SEM samples, is hardly surprising since abundant soil fungi $\left(10^{5}\right.$ to $10^{6}$ per gram; Maier et al., 2000) are to be expected in a biologically rich environment like POWI with access to significant organic carbon (Table 1). In addition, the cave is well connected hydrologically to the surface. No attempt was made in this study to employ molecular techniques to capture the actual identities of isolates or biodiversity of the deposits. A much more thorough and elaborate study will be needed to decipher the various relationships between cave communities and their potential parent populations on the surface.

Microbes present within these deposits have presumably been cave-selected for specific conditions, e.g. tolerance to changes in available nutrient concentrations and the absence of light. Presumably, the environment is selecting for a more depauperate microbial composition than the source materials. For example, the acidic nature of aboveground biomass means that there may be many organisms that cannot tolerate well the constantly buffered carbonate reservoir below ground (Alban, 1969; Turner \& Franz, 1985; Edmonds et al., 1991). The degree to which subsequent evolutionary development of unique caveadapted strains has progressed could be used as some indication of the age of the cave and time since it was first microbially colonized. However, because this is a shallow cave, clearly well connected to the surface, constant reinoculation of new organisms may well dominate over any intrinsic evolutionary developments. This remains to be determined.

Cottonball isolates from cultivation with calcium succinate as the only carbon source yielded significant precipitation of $\mathrm{CaCO}_{3}$ within biofilm. Chemical changes induced by biofilm presence leads to changes in $\mathrm{pH}$ and $\mathrm{Ca}^{2+}$ ion saturation conditions within growth media, causing precipitation of microcrystalline calcite rhombs and amorphous morphologies (Danielli $\&$ Edington, 1983). These culturable biofilm-crystal forming microbes in our study may or may not be the only microorganisms with calcite precipitation ability in these deposits, however, its presence shows that microbial influence on precipitation is plausible in this case. While it is true that bacterial species are known to produce different mineralogies and morphologies in different environments (Ercole et al., 2001), the intrinsic capability of the culturable microorganisms to influence crystallization within their biofilm does exist within the pools and moonmilk.

Some of the calcite crystal morphologies displayed within our cottonball Variant 3 cultures morphologically resemble calcite crystals produced by soil bacteria cultures on acetate and citrate-rich media in other studies (Verrecchia et al., 2003). Other experiments similar to ours have shown that calcite 
crystallization from soil bacteria utilize a fungal byproduct, Ca-oxalate, as a carbon source; thereby, increasing the $\mathrm{pH}$ and causing precipitation (Danielli \& Edington, 1983; Verrecchia et al., 2003).

\section{CONCLUSIONS}

From this preliminary study, we infer that both cottonballs and moonmilk are examples of a set of related processes that could collectively be accommodated by the traditional term "moonmilk". There are important similarities between them: 1) both deposits display aggregates of microcrystalline needle-fiber calcite morphologies, 2) they both contain significant biological filament and fibrous mats, 3) presence of organic carbon, 4) the organic carbon $\delta^{13} \mathrm{C}_{\text {org }}$ values of both deposits are similar, and 5) overall microbial abundances are relatively similar ( $\left.10^{6} \mathrm{CFU} / \mathrm{g}\right)$. In contrast, differences between the materials may largely be attributable to the immediate milieu, namely deposition in air or in water. Compared to the moonmilk, the cottonballs are: 1) less dense, 2) the biological filaments are thus, more visually noticeable, 3) detailed morphology differs (e.g., moonmilk is polycrystalline dominated, cottonballs are monocrystalline dominated), and 4) the overall whole carbon $\delta^{13} \mathrm{C}$ value of the cottonballs are isotopically lighter than the moonmilk.

Due to the complexity of these deposits, the individual processes and origins of the carbon are difficult to distinguish. However, it is clear that the shallow nature of the cave and the high aboveground biomass link the two habitats closely in terms of fixed carbon and other nutrient flow. This can be seen in the large amount of overall biomass present in these deposits compared to most caves in other, less nutrient rich environments, or found at greater depths.

Many of the organisms found in the cave probably have filtered in with seepage water in the past. In addition, this cave has an external entrance through which other organisms could be transported by air currents. Environmental selection (subaqueous and subaerial, aerobic to anaerobic) may cause the structure and dominant microorganisms within each deposit to vary drastically. Interestingly, even though such drastic variations exist within each microbial community, both environments are capable of producing complex microcrystalline calcite mineralization. Future work should be directed towards answering a number of important questions. These include: 1) fine scale dissolved oxygen and nutrient gradients within pools and moonmilk on a centimeter scale, 2) overall biodiversity of microbial populations, 3) presence and potential role of anaerobes, 4) details of the precipitation chemistry facilitated by the microorganisms, and 5) the degree to which the microbial populations overlap with each other and with the presumed source population in the surface soils.

Compared to other needle-fiber and microbial precipitation studies (Verrecchia et al., 1993; Verrecchia \& Verrecchia, 1994; Gradziñski et al., 1997; Sanchez-Moral et al., 2003; Dupraz et al., 2008), and utilizing biogenic guidelines for secondary minerals within caves delineated by Barton et al. (2001), the significant presence of: 1) metabollicaly active microbes and biofilm producers, 2) bacterial filaments, hyphae, and fibrous nano-fiber mats, 3) significant microbial presence via total enumeration, 4) presence of organic matter, 5) depleted isotopic carbon signatures, and 6) composition of biologicallyinfluenced needle-fiber calcite suggest that both deposits may be classified as biologicallyinfluenced organomineral, which are influenced by both intrinsic microbial processes and extrinsic environmental processes. A study by Gradziñski et al. (1997) in which moonmilk speleothems from Poland were defined as mineral-organic mats in which texture was influenced by hydrodynamic controls, reached similar conclusions.

If we accept the definition of moonmilk commonly used, then the cottonbals fall into that same category and may represent a continuum of moonmilk deposits from subaerial to subaqueous that can provide us with a conceptual model of its formation. Recognition of a continuum of formation across widely differing conditions may help to refine our current rather loose and imprecise grasp of the nature of moonmilk (Onac \& Ghergari, 1993).

\section{ACKNOWLEDGMENTS}

Funding for this project was provided by the National Cave and Karst Research Institute (NCKRI), American Association of Petroleum Geologists (AAPG), Cave Research Foundation (CRF), Geological Society of America (GSA), Karst Waters Institute (KWI), and the New Mexico Geological Society (NMGS). The authors acknowledge: the Tongass National Forest, Thorne Bay Ranger District; Andrea Martin Perez for her help in the field; Laura Rosales Lagarde, Sharie Houston, Kimberly Samuels, Art Palmer, and Peggy Palmer for stable isotope assistance; Dr. Tom Kieft for microbiological assistance and early reviews; Dr. Michael Pullin for carbon analyzer assistance, and Dr. Jim Connoly for XRD sample analyses at the University of New Mexico. Special thanks to Jo De Waele and anonymous reviewers for careful editing and constructive comments. This work is part of an unpublished Master of Science thesis (M.D. Curry, New Mexico Institute of Mining and Technology, Socorro, 2009).

\section{REFERENCES}

Alban D., 1969 - The Influence of Western Hemlock and Western Redcedar on Soil Properties. Soil Science Society of America Proceedings, 33: 453-457.

Allred K., 1992 - Cataract Cave: Prince of Wales Island. The Alaskan Caver, 12(1). In: 1992 Speleo Digest. Huntsville: National Speleological Society: 18-19.

Allred K., 2004 - Some Carbonate Erosion Rates of Southeast Alaska. Journal of Cave and Karst Studies, 66 (3): 88-97.

Atlas R. \& Parks L., 1993 - Handbook of Microbiological 
Media. CRC Press, Inc., Boca Raton, 1079 p.

Baichtal J.F. \& Swanston D.N., 1996 - Karst Landscapes and Associated Resources: A Resource Assessment. Gen. Tech. Rep. PNW-GTR-383. Portland, OR: U.S. Department of Agriculture, Forest Service, Pacific Northwest Research Station. 13 p.

Bajnóczi B. \& Kovács-Kis V., 2006 - Origin of pedogenic needle-fiber calcite revealed by micromorphology and stable-isotope composition - a case study of a Quaternary paleosol from Hungary. Chemie der Erde, 66: 203-212.

Barbieri A.J., 1993 - Depositos minerais secundarios das cavernas Santana, Perolas e Lage Branca, municipio de Iporanga-São Paulo. [MS thesis] São Paulo, Univ. São Paulo, 96 p.

Barton H.A., Spear J.R. \& Pace N.R., 2001 - Microbial life in the underworld: Biogenicity in secondary mineral formations. Geomicrobiology Journal, 18: 359-368.

Bernasconi R., 1976 - The physico-chemical evolution of moonmilk. Cave Geology, 3: 63-88.

Borsato A., Frisia S., Jones B. \& Van der Borg K., 2000 Calcite Moonmilk: Crystal Morphology and Environment of formation in Caves in the Italian Alps. Journal of Sedimentary Research, 70 (5): 1179-1190.

Boston P., Spilde M., Northup D., Melim L., Soroka D., Kleina L., Lavoie K., Hose L., Mallory L., Dahm C., Crossey L. \& Schelble R., 2001 - Cave biosignature suites: Microbes, minerals, and mars. Astrobiology, 1: 25-55.

Blyth A.J. \& Frisia S., 2008 - Molecular evidence for bacterial mediation of calcite formation in cold highaltitude caves. Geomicrobiology Journal, 25: 101-111.

Cañaveras J., Hoyos M., Sanchez-Moral S., Sanz-Rubio E., Bedoya J., Soler V., Groth I. \& Schumann P., 1999 Microbial communities associated with hydromagnesite and needle-fiber aragonite deposits in a karstic cave (Altamira, Northern Spain). Geomicrobiology Journal, 16: 9-25.

Cañaveras J., Cuezva S., Sanchez-Moral S., Lario J., Laiz L., Gonzalez J. \& Saiz-Jimenez C., 2006 - On the origin of fiber calcite crystals in moonmilk deposits. Naturwissenschaften, 93: 27-32.

Chirienco M., 2002 - Calcite moonmilk in the Humpleu Cave System (Romania): The relationship between crystal morphology and cave topoclimate. Cave and Karst Science, 29: 101-104.

Danielli H.M., \& Edington M.A., 1983 - Bacterial Calcification in Limestone Caves. Geomicrobiology Journal, 3: 1-16.

Dekker N.P., Lammel C.J. \& Brooks G.F., 1991 Scanning electron microscopy of piliated Neisseria gonorrhoeae processed with hexamethyldisilazane. Journal of Electronic Microscopy Technology, 19: 461-467.

Dove P., DeYoreo J. \& Weiner S. (Eds.), 2003 Biomineralization. Reviews in Mineralogy \& Geochemistry 54. Washington, DC: Mineralogical Society of America Geochemical Society, 381 p.

Dupraz C., Reid R.P., Braissant O., Decho A.W., Norman R.S. \& Visscher P.T., 2008 - Processes of carbonate precipitation in modern microbial mats. Earth-Science Reviews, in press. doi: 10.1016/j. earscirev.2008.10.005

Ercole C., Cacchio P., Cappuccio G. \& Lepidi A., 2001 - Deposition of calcium carbonate in karst caves: roles of bacteria in Stiffe's Cave. International Journal of Speleology, 30: 69-79.

Edmonds R.L., Thomas T.B. \& Rhodes J.J., 1991 Canopy and Soil Modification of Precipitation Chemistry in a Temperate Rain Forest. Soil Science Society of America Journal, 55: 1685-1693.

Ehrlich H.L., 1996 - Geomicrobiology. New York, Marcel Dekker, Inc., 719 p.

Fierer N. \& Jackson R.B., 2006 - The diversity and biogeography of soil bacterial communities. Proceedings of the National Academie of Sciences, 103 (3): 626631.

Fischer H., 1988 - Etymology, terminology, and an attempt of definition of mondmilch. NSS Bulletin, 50: 54-58.

Ford D. \& Williams P., 2007 - Karst Hydrogeology and Geomorphology. Chichester, John Wiley \& Sons, Ltd., $562 \mathrm{p}$.

Fornaca-Rinaldi G., Panichi C. \& Tongiorgi E., 1968 Some Causes of the Variation of the Isotopic Composition of Carbon and Oxygen in Cave Concretions. Earth \& Planetary Science Letters, 4: 321-324.

Friedman I. \& O'Neil J.R., 1977 - Compilation of stable isotope fractionation factors of geochemical interest. U.S. Geol. Surv. Prof. Pap. 440-KK, 49 p.

Garrels R.M. \& Christ C.L., 1965 - Solutions, Minerals and Equilibria. New York, Harper \& Row, New York, $450 \mathrm{p}$.

Garrett S.D., 1963 - Soil Fungi and Soil Fertility. New York, The Macmillan Company, $165 \mathrm{p}$.

Gèze B., 1976 - Actual status of the question of “moonmilk". Cave Geology, 3: 57-62.

Gradziñski M., Szulc J., \& Smyk B., 1997 - Microbial Agents of Moonmilk Calcification. In: Proceedings of the 12th International Congress of Speleology; La Chaux-de-Fonds, 1: 275-278

Hendy C.H., 1971 - The Isotopic Geochemistry of Speleothems - I. The Calculation of the Effects of Different Modes of Formation on the Isotopic Composition of Speleothems and Their Applicability as Paleoclimatic Indicators. Geochimica et Cosmochimica Acta, 35: 801-824.

Hill C.A. \& Forti P., 1997 - Cave Minerals of the World. Huntsville, National Speleological Society, 463 p.

Hoeffs J., 2004 - Stable Isotope Geochemistry. New York, Springer, $244 \mathrm{p}$.

Høeg O.A., 1946 - Cyanophyceae and bacteria in calcareous sediments in the interior of limestone caves in Nord-Rana, Norway. Nytt Mag. Naturvidenspene, 85: 99-104

Jones B. \& Kahle C., 1993 - Morphology, relationship, and origin of fiber and dendrite calcite crystals. Jouranl of Sedimentary Petrology, 63 (6): 1018-1031.

Kepner R.L., Jr. \& Pratt J.R., 1994 - Use of Fluorochromes for Direct Enumeration of Total Bacteria in Environmental Samples: Past and Present. Microbiological Reviews, 58 (4): 603-615.

Klimchouk A.B. \& Gudzenko V.V., 1996 - Chernobyl radiocaesium in a karst system, Marble Cave, Crimea. Environmental Geology, 28: 161-166. 
Lacelle D., Lauriol B. \& Clark I.D., 2004 - Seasonal isotopic imprint in moonmilk from Caverne de l'Ours (Quebec, Canada): implications for climatic reconstruction. Canadian Journal of Earth Science, 41: 1411-1423.

Langmuir D. 1997 - Aqueous environmental chemistry. Upper Saddle River, Prentice Hall, 600 p.

Maier R., Peppe, I. \& Gerba C., 2000 - Environmental Microbiology. New York, Academic Press. 585 p.

Martìn-Pèrez, 2006 - Formación de Dolomita y Huntita en Ambiente Meteórico Vadoso. Cueva de Castañar de Ibor (Cáceres). [MS Thesis] Madrid, Universidad Complutense de Madrid - CSIC, $61 \mathrm{p}$.

Martinez-Arkarazo I., Angulo M., Zuloaga O., Usobiaga A. \& Madarìaga J.M., 2007 - Spectroscopic characterization of moonmilk deposits in Pozalagua tourist Cave (Karrantza, Basque Country, North of Spain). Spectrochimica Acta Part A, 68: 1058-1064.

McDermott F., 2004 - Palaeo-climate reconstruction from stable isotope variations in speleothems: a review. Quaternary Science Reviews, 23: 901-918.

Mickler P.J., Stern L.A. \& Banner J.L., 2006 - Large kinetic isotope effects in modern speleothems. GSA Bulletin, 118: 65-81.

Moore G.W. \& Sullivan N., 1997 - Behavior and Products of Cave Microorganisms. In: Speleology: Caves and the Cave Environment, St. Louis, Cave Books, 176 p.

Mulec J., Zalar P., Zupan Hajna N. \& Rupnik M., 2002 - Screening for Culturable Microorganisms from Cave Environments (Slovenia). Acta Carsologica, 31 (2): 177-187.

Northup D. \& Lavoie K., 2001 - Geomicrobiology of Caves: A Review. Geomicrobiology Journal, 18: 199-222.

Onac B.P., 1995 - Mineralogical data concerning moonmilk speleothems in few caves from northern Norway. Acta Carsologica, 24: 429-437.

Onac B.P. \& Ghergari L., 1993 - Moonmilk mineralogy in some Romanian and Norwegian Caves. Cave Science, 20: $106-120$.

O’Neil J.R., Clayton R.N. \& Mayeda T.K., 1969 - Oxygen isotope fractionation in divalent metal carbonates. The Journal of Chemical Physics, 51: 5547-5558.

Palmer A., 2007 - Cave Geology. Dayton, Cave Books, $454 \mathrm{p}$.

Perrone M., 2005 - Experimental determination of the biogenicity of moonmilk, and the characterization of moonmilk and its depositional environment in Spider Cave, Carlsbad Caverns National Park, New Mexico. [MS thesis] Las Cruces, New Mexico State University.

Perrone M., Giles K., Boston P., Northup D. \& Spilde M., 2004 - Experimental determination of the biogenicity of moonmilk, and the characterization of moonmilk and its depositional environment in Spider Cave, Carlsbad Caverns National Park, New Mexico. Geological Society of America, Abstracts with programs, 34 (8): 361.
Richter D.K., Immenhauser A. \& Neuser R.D., 2008 Electron backscatter diffraction documents randomly orientated c-axes in moonmilk calcite fibres: evidence for biologically induced precipitation. Sedimentology, 55: 487-497.

Sanchez-Moral S., Cañaveras J.C., Laiz L., SaizJimenez, Bedoya J. \& Luque L., 2003 - Biomediated precipitation of calcium carbonate metastable phase in hypogean environments: A short review. Geomicrobiology Journal, 20: 491-500.

Schidlowski M., 2000 - Carbon Isotopes \& Microbial Sediments. In: Riding R. \& Awramik S. M. (Eds.), Microbial Sediments. New York: Springer: 84-104.

Sharp Z., 2007 - Principles of Stable Isotope Geochemistry. Upper Saddle River, Prentice Hall, 344 p.

Shumenko S.I. \& Olimpiev I.V., 1977 - Rock milk from caves in Crimea and Abhasia. Lithology and Mineral Resources, 12: 240-243.

Spilde M., Northup D., Boston P., Schelble R., Dano K., Crossey L., and Dahm C., 2005 - Geomicrobiology of Cave Ferromanganese Deposits: A Field and Laboratory Investigation. Geomicrobiology Journal, 22: 99-116.

Sumner D.Y., 2001 - Microbial Influences on Local Carbon Isotopic Ratios and Their Preservation in Carbonate. Astrobiology, 1 (1): 57-70.

Taylor P.M. \& Chafetz H.S., 2004 - Floating Rafts of Calcite Crystals in Cave Pools, Central Texas, USA: Crystal Habit vs. Saturation State. Journal of Sedimentary Research, 74 (3): 328-341.

Turner D.P. \& Franz E.H., 1985 - The influence of western hemlock and western red cedar on microbial numbers, nitrogen mineralization, and nitrification. Plant \& Soil, 88: 259-267.

van de Kamp J., 2004 - Microbial biodiversity in Tasmanian Caves. [Ph. D. thesis] Tasmania, University of Tasmania.

Verrecchia E.P., Dumont J.-L. \& Verrecchia K.E., 1993 - Role of Calcium Oxalate Biomineralization by Fungi in the Formation of Calcretes: A Case Study from Nazareth, Israel. Journal of Sedimentary Petrology, 63 (5): 10001006.

Verrecchia E.P. \& Verrecchia K.E., 1994 - Needle-fiber Calcite: A Critical Review and a proposed Classification. Journal of Sedimentary Research, A64 (3): 650-664.

Verrecchia E.P., Loisy C., Braissant O. \& Gorbushina A.A., 2003 - The Role of Fungal Biofilm and Networks in the Terrestrial Calcium Carbonate Cycle. In: Krumbein W.E., Paterson D.M. \& Zavarzin G.A. (Eds.), Fossil and Recent Biofilms: A Natural History of Life on Earth. Boston, Kluwer Academic Publishers: 363-369.

Wilkinson H.P., 2003 - Fossil actinomycetefilaments and fungal hyphae in dicotyledonous wood from the Eocene London Clay, Isle-of-Sheppey, Kent, England. Botanical Journal of the Linnean Society, 142: 383-394. 